\title{
Host-guest complexes of mixed glycol-bipyridine cryptands: prediction of ion selectivity by quantum chemical calculations, part V
}

\author{
Svetlana Begel ${ }^{1}$, Ralph Puchta ${ }^{* 1,2}$ and Rudi van Eldik ${ }^{1}$
}

\section{Full Research Paper}

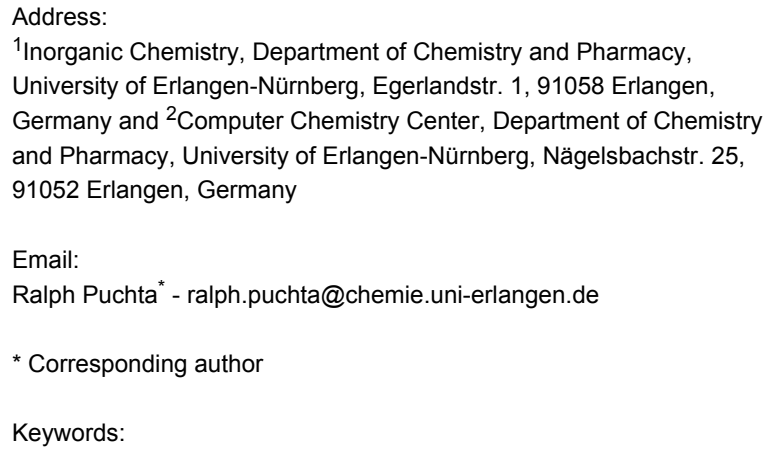

Beilstein J. Org. Chem. 2013, 9, 1252-1268. doi:10.3762/bjoc. 9.142

Received: 11 January 2013

Accepted: 08 June 2013

Published: 27 June 2013

Dedicated to Professor Peter Comba on the occasion of his 60th birthday. For part IV see: [1]

Associate Editor: S. C. Zimmerman

(C) 2013 Begel et al; licensee Beilstein-Institut. License and terms: see end of document.

\begin{abstract}
The selectivity of the cryptands [2.2.bpy] and [2.bpy.bpy] for the endohedral complexation of alkali, alkaline-earth and earth metal ions was predicted on the basis of the DFT (B3LYP/LANL2DZp) calculated structures and complex-formation energies. The cavity size in both cryptands lay between that for [2.2.2] and [bpy.bpy.bpy], such that the complexation of $\mathrm{K}^{+}, \mathrm{Sr}^{2+}$ and $\mathrm{Tl}^{3+}$ is most favorable. While the [2.2.bpy] is moderately larger, preferring $\mathrm{Rb}^{+}$complexation and demonstrating equal priority for $\mathrm{Sr}^{2+}$ and $\mathrm{Ba}^{2+}$, the slightly smaller [2.bpy.bpy] yields more stable cryptates with $\mathrm{Na}^{+}$and $\mathrm{Ca}^{2+}$. Although the $\mathrm{CH}_{2}$-units containing molecular bars fixed at the bridgehead nitrogen atoms determine the flexibility of the cryptands, the twist angles associated with the bipyridine and glycol building blocks also contribute considerably.
\end{abstract}

\section{Introduction}

The present report continues a series of contributions from our group dealing with quantum chemical investigations of the selective complexation of alkali and alkaline-earth metal cations by supramolecular species, predominantly cryptands and their derivatives [1-4]. The current state of research relevant for our studies was carefully explored and illustrated in the mentioned publications and will therefore not be repeated in detail in this work.
Selective complexation of molecules and ions is one of the most important topics in bio-inorganic supramolecular chemistry, which requires detailed and elaborate examination due to its significant role in receptors in biological and technical systems. Selectivity phenomena have been studied for over 80 years $[5,6]$. During this period of time versatile model systems with variable cavity sizes have been investigated experimentally as well as by computational methods to gain information about the 
geometric and electronic demands of this process [7-10]. Wellknown supramolecular species, e.g., calixarenes [11-15], cyclodextrines [16], crown ethers [17-22], cryptands [23,24] and the corresponding metallatopomers, easily accessible by self-organisation [25-36], can be taken as examples for such model systems.

Kryptofix 222 ([2.2.2] or 4,7,13,16,21,24-hexaoxa-1,10-diazabicyclo[8.8.8]hexacosane) (Figure 1), synthesized by Lehn 40 years ago [37] is still very popular and widely used today, especially due to its ability to bind ions selectively, primarily alkali and alkaline earth metal cations [38-49]. In contrast, derivatives of this cryptand containing, for example, nitrogen donor atoms ([phen.phen.phen] and [bpy.bpy.bpy]) as well as the hybrids between them and [2.2.2] have not yet been studied sufficiently [50-58]. While the main concern was their photophysical and photochemical properties [51,52,54-56,59,60], their ability for selective complexation was not investigated experimentally.

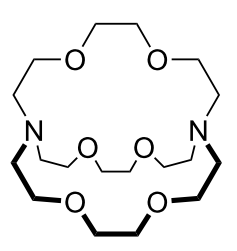

Figure 1: Structure of [2.2.2] also known as 4,7,13,16,21,24-hexaoxa1,10-diazabicyclo[8.8.8]hexacosane or Kryptofix 222.

As mentioned above, the complexation of alkali and alkalineearth metal ions by different cryptands was investigated extensively in our group on the basis of DFT (B3LYP/LANL2DZp) calculations [1-4]. Within the framework of this study, nondynamic quantum chemical calculations, performed in the absence of solvent molecules and focusing on the system itself, were utilized very successfully for the careful examination of the supramolecules, excluding possible disturbing side effects.

The current work extends our explorations into the outlined topic. Here we discuss two hybrid cryptands between [2.2.2] and [bpy.bpy.bpy]. They are abbreviated as [2.2.bpy] and [2.bpy.bpy] and are presented in Figure 2.

\section{Results and Discussion}

Although as of spring 2013 more than 650 X-ray structures are listed in the Cambridge Structural Database for [2.2.2] and mostly its alkali and alkaline-earth metal cryptate complexes, only the structure of [ $\mathrm{Na} \subset 2$ 2.2.bpy] Br has been published [61], and to the best of our knowledge there are no further experimental structures for [2.2.bpy] and [2.bpy.bpy] cryptands and

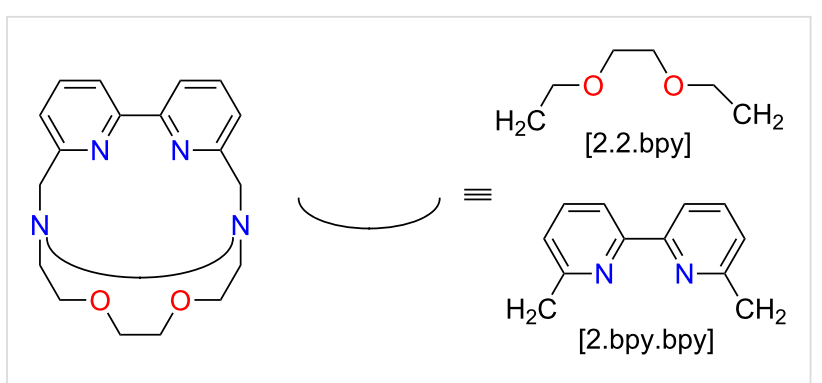

Figure 2: Structures of [2.2.bpy] and [2.bpy.bpy].

cryptate complexes. In earlier investigations on related supramolecular systems the applied method (RB3LYP/LANL2DZp) provided satisfactory results [1-4]. In all these cases the calculated bond length between the guest ions and the donor atoms was elongated compared to the analogous bonds in the X-ray structures. The same behavior is found when comparing [Na $\subset$ 2.2.bpy]Br and the (B3LYP/LANL2DZp) calculated $C_{2}$ symmetric $[\mathrm{Na} \subset 2.2 . b p y]^{+}$-ion. The bonds between the sodium cation and the donor atoms are around 5.5\% longer than in the averaged solid-state structure (Table 1). Whereas Table 1 and Table 2 present significant data for all discussed structures, Figure 3 and Figure 4 illustrate, as representative examples, the calculated $[\mathrm{K} \subset 2.2 \text {.bpy }]^{+}$and $[\mathrm{K} \subset 2 \text { 2.bpy.bpy }]^{+}$. Table 3 and Table 4 summarize the values for the complexation energies of the studied cryptate complexes.

Whereas [2.2.2] [2], [bpy.bpy.bpy] and [phen.phen.phen] [4] demonstrate $D_{3}$ symmetry, the cryptands studied in this work, [2.2.bpy] and [2.bpy.bpy], are mostly $C_{2}$ symmetric, like the arrangement found for [2.2.phen] and [2.phen.phen] [1]. For this reason [2.2.bpy] and [2.bpy.bpy] are able to host even small cations such as $\mathrm{Be}^{2+}, \mathrm{Al}^{3+}, \mathrm{Ga}^{3+}$ and $\mathrm{Li}^{+}$effectively. They mostly prefer coordination to the nitrogen donor atoms, while for the larger ions the interaction with the oxygen donors also plays an important role.

Except for $[\mathrm{Mg} \subset 2.2 . \mathrm{bpy}]^{2+}$ and $[\mathrm{Ga} \subset 2.2 . \mathrm{bpy}]^{3+}$, all structures are local minima on the potential hypersurface, as noted in Table 3. The $C_{2}$ structures of $[\mathrm{Mg} \subset 2.2 . \mathrm{bpy}]^{2+}$ and $[\mathrm{Ga} \subset 2.2 . \mathrm{bpy}]^{3+}$ are transition states for the movement of the metal ion inside the cavity of [2.2.bpy], as shown in Figure 5.

This motion leads from one glycol molecular bar to the other, bringing the cation closer to the $\mathrm{O}$ donor atoms, hence supporting the coordination. The barrier for this movement lies at $1.6 \mathrm{kcal} / \mathrm{mol}$ and $20.1 \mathrm{kcal} / \mathrm{mol}$, respectively. The high value for the movement of $\mathrm{Ga}^{3+}$ inside the [2.2.bpy] results from the very effective complexation of earth metal ions by cryptands compared with single solvent molecules, e.g., $\mathrm{H}_{2} \mathrm{O}$ or $\mathrm{NH}_{3}$, and hence, a large amount of released free energy. 
Table 1: Calculated (RB3LYP/LANL2DZp) structural data for the metal-donor interactions in $[M \subset 2.2 . b p y]^{\mathrm{m}+}\left(\right.$ calculated structures: $C_{2}$ symmetry); (x): averaged experimental X-ray structural data [61]

\begin{tabular}{|c|c|c|c|c|c|c|c|}
\hline & $\begin{array}{l}\mathrm{M}-\mathrm{N}_{\mathrm{sp} 2} \\
{[\AA]}\end{array}$ & $\begin{array}{l}\mathrm{M}-\mathrm{N}_{\mathrm{sp} 3} \\
{[\AA]}\end{array}$ & $\begin{array}{l}\mathrm{M}-\mathrm{O} \\
[\AA]]\end{array}$ & $\begin{array}{l}\mathrm{N}_{\mathrm{sp} 2}-\mathrm{C} \cdot \cdots \cdot \mathrm{C}-\mathrm{N}_{\mathrm{sp} 2} \\
{\left[{ }^{\circ}\right]}\end{array}$ & $\begin{array}{l}\mathrm{CH}_{2}-\mathrm{N}_{\mathrm{sp} 3} \bullet \cdot \mathrm{N}_{\mathrm{sp} 3}-\mathrm{CH}_{2} \\
{\left[{ }^{\circ}\right]}\end{array}$ & $\begin{array}{l}\mathrm{O}-\mathrm{C} \cdot \cdots \mathrm{C}-\mathrm{O} \\
\left.{ }^{\circ}\right]\end{array}$ & $\begin{array}{l}\mathrm{CH}_{2}-\mathrm{CH}_{2}-\mathrm{N}_{\mathrm{sp} 3} \cdots \\
\mathrm{N}_{\mathrm{sp} 3}-\mathrm{CH}_{2}-\mathrm{CH}_{2} \\
{\left[{ }^{\circ}\right]}\end{array}$ \\
\hline empty & - & - & - & 132.3 & 10.0 & 164.3 & 10.3 \\
\hline $\mathrm{Li}^{+}\left(C_{1}\right)$ & $\begin{array}{l}2.24 \\
2.16\end{array}$ & $\begin{array}{l}2.58 \\
2.87\end{array}$ & $\begin{array}{l}3.19 \\
3.01 \\
3.07 \\
3.29\end{array}$ & 5.8 & -92.5 & $\begin{array}{l}56.8 \\
56.1\end{array}$ & $\begin{array}{l}-91.0 \\
-88.5\end{array}$ \\
\hline $\mathrm{Li}^{+}$ & 2.19 & 2.71 & $\begin{array}{l}3.15 \\
3.12\end{array}$ & 5.0 & -93.8 & 56.0 & -91.1 \\
\hline $\mathrm{Na}^{+}$ & 2.79 & 2.90 & $\begin{array}{l}2.84 \\
2.81\end{array}$ & 29.0 & -67.0 & 59.0 & -69.0 \\
\hline $\mathrm{Na}^{+}(\mathrm{x})$ & 2.61 & 2.76 & $\begin{array}{l}2.66 \\
2.68\end{array}$ & 24.9 & -78.6 & -61.4 & -77.3 \\
\hline $\mathrm{K}^{+}$ & 2.95 & 3.03 & $\begin{array}{l}2.89 \\
2.84\end{array}$ & 42.3 & -44.4 & 64.3 & -47.0 \\
\hline $\mathrm{Rb}^{+}$ & 3.02 & 3.07 & $\begin{array}{l}2.94 \\
2.92\end{array}$ & 47.9 & -36.2 & 68.5 & -38.2 \\
\hline $\mathrm{Cs}^{+}$ & 3.12 & 3.12 & $\begin{array}{l}3.02 \\
3.03\end{array}$ & 56.1 & -28.8 & 76.0 & -30.2 \\
\hline $\mathrm{Be}^{2+}\left(C_{1}\right)$ & $\begin{array}{l}1.78 \\
1.66\end{array}$ & $\begin{array}{l}1.83 \\
3.64\end{array}$ & $\begin{array}{l}1.65 \\
3.76 \\
4.50 \\
3.92\end{array}$ & 3.0 & -123.1 & $\begin{array}{l}55.5 \\
76.2\end{array}$ & $\begin{array}{l}-89.6 \\
-120.1\end{array}$ \\
\hline $\mathrm{Be}^{2+}$ & 1.79 & 1.95 & $\begin{array}{l}3.24 \\
3.65\end{array}$ & 3.2 & -136.0 & 49.6 & -120.2 \\
\hline $\mathrm{Mg}^{2+}\left(C_{1}\right)$ & $\begin{array}{l}2.24 \\
2.23\end{array}$ & $\begin{array}{l}2.47 \\
2.57\end{array}$ & $\begin{array}{l}2.33 \\
2.27 \\
3.42 \\
3.45\end{array}$ & -5.2 & -113.0 & $\begin{array}{l}50.9 \\
41.9\end{array}$ & $\begin{array}{l}-112.7 \\
-105.8\end{array}$ \\
\hline $\mathrm{Mg}^{2+}$ (T.S.) & 2.29 & 2.48 & $\begin{array}{l}2.71 \\
2.74\end{array}$ & -7.9 & -116.9 & 47.2 & 4.5 \\
\hline $\mathrm{Ca}^{2+}$ & 2.68 & 2.74 & $\begin{array}{l}2.68 \\
2.68\end{array}$ & -6.2 & -92.8 & 49.8 & -94.5 \\
\hline $\mathrm{Sr}^{2+}$ & 2.81 & 2.87 & $\begin{array}{l}2.77 \\
2.76\end{array}$ & 20.0 & -72.6 & 52.9 & -74.5 \\
\hline $\mathrm{Ba}^{2+}$ & 2.92 & 2.98 & $\begin{array}{l}2.86 \\
2.84\end{array}$ & 31.5 & -50.1 & 57.0 & -52.7 \\
\hline $\mathrm{Al}^{3+}$ & 2.07 & 3.13 & $\begin{array}{l}2.02 \\
2.09\end{array}$ & -24.4 & -86.7 & 40.1 & -82.1 \\
\hline $\mathrm{Ga}^{3+}\left(C_{1}\right)$ & $\begin{array}{l}2.05 \\
2.05\end{array}$ & $\begin{array}{l}2.22 \\
2.20\end{array}$ & $\begin{array}{l}2.11 \\
2.16 \\
3.76 \\
3.80\end{array}$ & -0.3 & -127.1 & $\begin{array}{l}48.0 \\
-38.4\end{array}$ & $\begin{array}{l}-113.1 \\
-6.7\end{array}$ \\
\hline $\mathrm{Ga}^{3+}$ (T.S.) & 2.06 & 2.14 & $\begin{array}{l}2.86 \\
3.01\end{array}$ & -0.7 & -130.8 & 41.4 & -125.6 \\
\hline $\ln ^{3+}$ & 2.31 & 2.48 & $\begin{array}{l}2.46 \\
2.47\end{array}$ & -12.4 & -126.3 & 42.3 & -127.1 \\
\hline $\mathrm{Tl}^{3+}$ & 2.48 & 2.55 & $\begin{array}{l}2.71 \\
2.73\end{array}$ & -6.2 & -111.2 & 49.1 & -111.6 \\
\hline
\end{tabular}

The presented work was initiated with the objective to systematically study the selective complexation of alkali, alkalineearth and earth metal cations by [2.2.bpy] and [2.bpy.bpy] cryptands. In general, the prediction of a favorable complexation can be made based on two characteristics, viz., bond distances and energies of model reactions, as was shown in previous contributions from our group [1-4]. A comparison of the bond distances between the donor atoms and the metal cation complexed endohedrally by the cryptand or by the solvent molecules, e.g., pyridine or water, can be drawn. This method only provides reliable results if the donor atoms that coordinate to the metal center are the same and in an equal 


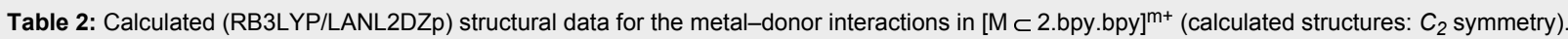

$\begin{array}{lllllll}\mathrm{M}-\mathrm{N}_{\mathrm{sp} 2} & \mathrm{M}-\mathrm{N}_{\mathrm{sp} 3} & \mathrm{M}-\mathrm{O} & \mathrm{N}_{\mathrm{sp} 2}-\mathrm{C} \cdot \cdots \mathrm{C}-\mathrm{N}_{\mathrm{sp} 2} & \mathrm{CH}_{2}-\mathrm{N}_{\mathrm{sp} 3} \cdot \cdots \mathrm{N}_{\mathrm{sp} 3}-\mathrm{CH}_{2} & \mathrm{O}-\mathrm{C} \cdot \cdots \mathrm{C}-\mathrm{O} & \mathrm{CH} \\ {[\AA]} & {[\AA]} & {[\AA]} & {\left[^{\circ}\right]} & \left.{ }^{\circ}\right] & {\left[{ }^{\circ}\right]} & { }^{\circ}\end{array}$

$\mathrm{CH}_{2}-\mathrm{CH}_{2}-\mathrm{N}_{\mathrm{sp} 3} \cdots$

\begin{tabular}{|c|c|c|c|c|c|c|c|}
\hline & \multirow[b]{2}{*}{-} & & \multirow[b]{2}{*}{-110} & \\
\hline empty & - & & - & 59.2 & & 79.9 & -43.9 \\
\hline $\mathrm{Li}^{+}$ & $\begin{array}{l}2.37 \\
2.44\end{array}$ & 2.82 & 3.42 & -12.4 & -97.0 & 58.0 & -94.1 \\
\hline $\mathrm{Na}^{+}$ & $\begin{array}{l}2.78 \\
2.79\end{array}$ & 2.84 & 2.89 & 23.8 & -75.9 & 58.2 & -77.0 \\
\hline $\mathrm{K}^{+}$ & $\begin{array}{l}2.91 \\
2.93\end{array}$ & 2.96 & 2.84 & 34.6 & -59.6 & 62.7 & -61.9 \\
\hline $\mathrm{Rb}^{+}$ & $\begin{array}{l}2.98 \\
3.00\end{array}$ & 3.04 & 2.90 & 43.7 & -46.4 & 68.0 & -48.7 \\
\hline $\mathrm{Cs}^{+}$ & $\begin{array}{l}3.08 \\
3.09\end{array}$ & 3.11 & 2.98 & 53.7 & -36.8 & 77.1 & -38.6 \\
\hline $\mathrm{Be}^{2+}\left(C_{1}\right)$ & $\begin{array}{l}1.69 \\
1.81 \\
1.77 \\
3.25\end{array}$ & $\begin{array}{l}1.90 \\
4.48\end{array}$ & $\begin{array}{l}3.62, \\
4.84\end{array}$ & $\begin{array}{l}-42.9 \\
-0.3\end{array}$ & $\begin{array}{l}-102.0 \\
-101.2\end{array}$ & 61.1 & -96.5 \\
\hline $\mathrm{Be}^{2+}$ & $\begin{array}{l}1.82 \\
1.89\end{array}$ & 2.92 & 4.17 & -10.1 & -114.5 & 55.8 & -96.5 \\
\hline $\mathrm{Mg}^{2+}\left(C_{1}\right)$ & $\begin{array}{l}2.41 \\
2.32 \\
2.34 \\
2.50\end{array}$ & $\begin{array}{l}2.97 \\
2.62\end{array}$ & $\begin{array}{l}2.31 \\
2.55\end{array}$ & $\begin{array}{l}-20.1 \\
-21.4\end{array}$ & $\begin{array}{l}-109.2 \\
-107.6\end{array}$ & 47.7 & -106.6 \\
\hline $\mathrm{Mg}^{2+}$ & $\begin{array}{l}2.28 \\
2.33\end{array}$ & 2.65 & 2.34 & -10.4 & -109.1 & 51.6 & -104.3 \\
\hline $\mathrm{Ca}^{2+}$ & $\begin{array}{l}2.69 \\
2.70\end{array}$ & 2.75 & 2.69 & -10.5 & -94.0 & 50.0 & -95.9 \\
\hline $\mathrm{Sr}^{2+}$ & $\begin{array}{l}2.81 \\
2.82\end{array}$ & 2.84 & 2.77 & 16.1 & -76.9 & 52.5 & -78.5 \\
\hline $\mathrm{Ba}^{2+}$ & $\begin{array}{l}2.91 \\
2.92\end{array}$ & 2.96 & 2.84 & 28.4 & -57.2 & 56.7 & -59.5 \\
\hline $\mathrm{Al}^{3+}$ & $\begin{array}{l}2.04 \\
2.08\end{array}$ & 2.34 & 3.83 & -5.6 & -126.2 & 48.4 & -114.0 \\
\hline $\mathrm{Ga}^{3+}$ & $\begin{array}{l}2.07 \\
2.12\end{array}$ & 2.42 & 3.77 & -6.0 & -123.2 & 48.2 & -112.0 \\
\hline $\ln ^{3+}$ & $\begin{array}{l}2.34 \\
2.37\end{array}$ & 2.64 & 2.56 & -17.2 & -121.7 & 45.8 & -122.5 \\
\hline $\mathrm{Tl}^{3+}$ & $\begin{array}{l}2.51 \\
2.53\end{array}$ & 2.65 & 2.82 & -12.6 & -109.0 & 50.5 & -109.1 \\
\hline
\end{tabular}
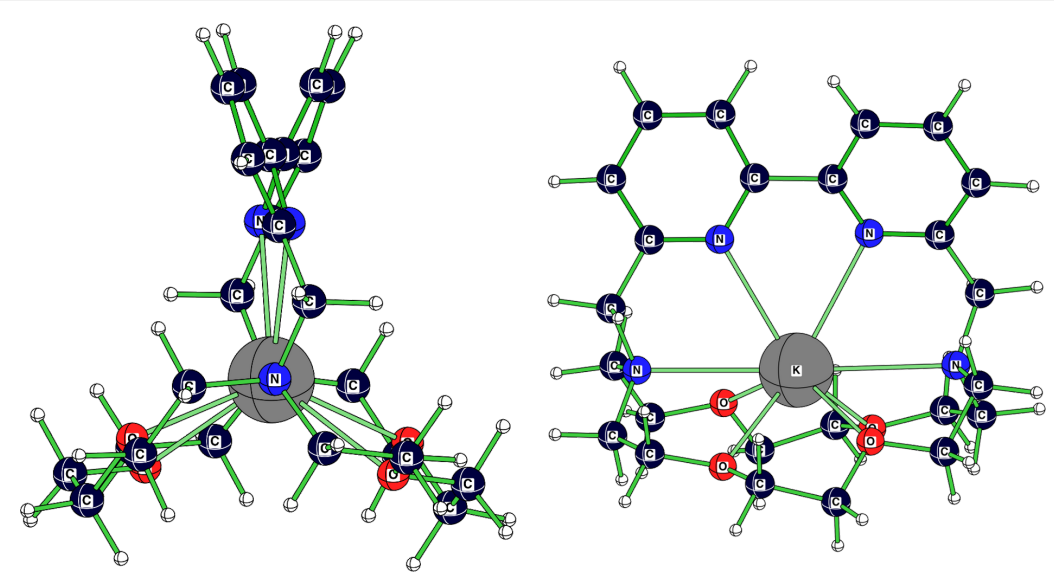

Figure 3: Calculated (RB3LYP/LANL2DZp) structure $\left(C_{2}\right)$ for $[K \subset 2.2 . b p y]^{+}$. 

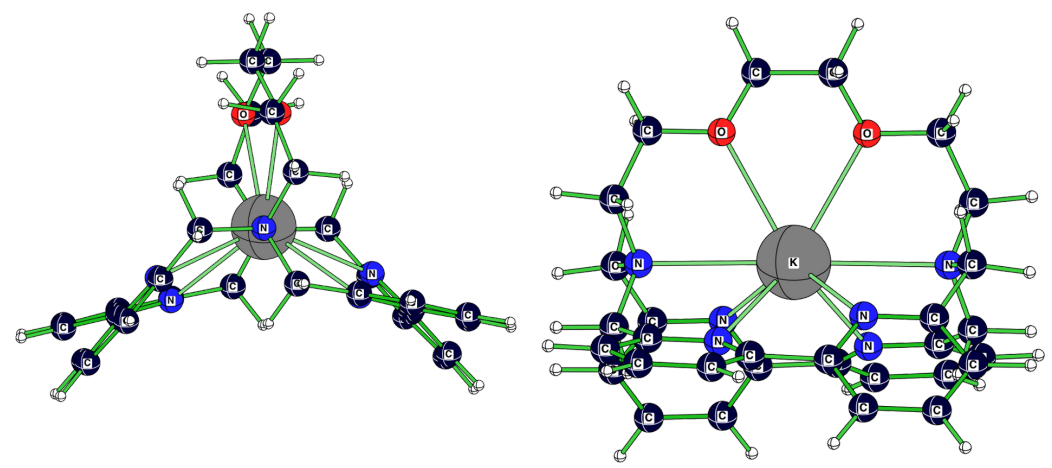

Figure 4: Calculated (RB3LYP/LANL2DZp) structure $\left(C_{2}\right)$ for $[\mathrm{K} \subset 2 . b p y . b p y]^{+}$.

\begin{tabular}{|c|c|c|c|}
\hline metal ions & $\Delta E_{\text {tot }}$ & $\triangle \mathrm{ZPE}$ & $\begin{array}{l}\text { complexation } \\
\text { energy }\end{array}$ \\
\hline $\mathrm{Li}^{+}$ & 23.0 & -5.8 & 17.2 \\
\hline $\mathrm{Li}^{+}\left(C_{1}\right)$ & 23.1 & -5.9 & 17.2 \\
\hline $\mathrm{Na}^{+}$ & 9.6 & -5.1 & 4.5 \\
\hline $\mathrm{K}^{+}$ & 1.8 & -5.4 & -3.6 \\
\hline $\mathrm{Rb}^{+}$ & -7.3 & -5.5 & 1.8 \\
\hline $\mathrm{Cs}^{+}$ & 18.5 & -4.9 & 13.6 \\
\hline $\mathrm{Be}^{2+}$ & 6.7 & -9.6 & -3.1 \\
\hline $\mathrm{Be}^{2+}\left(C_{1}\right)$ & -11.9 & -10.1 & -22.0 \\
\hline $\mathrm{Mg}^{2+}\left(C_{1}\right)$ & 9.1 & -9.0 & 0.1 \\
\hline $\mathrm{Mg}^{2+}$ (T.S.) & 10.7 & -9.0 & 1.7 \\
\hline $\mathrm{Ca}^{2+}$ & -14.1 & -8.3 & -22.3 \\
\hline $\mathrm{Sr}^{2+}$ & -18.4 & -8.0 & -26.4 \\
\hline $\mathrm{Ba}^{2+}$ & -19.1 & -7.0 & -26.1 \\
\hline $\mathrm{Al}^{3+}$ & -74.3 & -19.2 & -93.5 \\
\hline $\mathrm{Ga}^{3+}$ (T.S.) & -62.9 & -18.1 & -81.0 \\
\hline $\mathrm{Ga}^{3+}\left(C_{1}\right)$ & -83.1 & -18.0 & -101.1 \\
\hline $\ln ^{3+}$ & -75.9 & -17.0 & -92.9 \\
\hline $\mathrm{Tl}^{3+}$ & -111.2 & -15.9 & -127.1 \\
\hline
\end{tabular}

Table 4: Energy contributions (kcal/mol) to the complexation energy for $[M \subset 2 . b p y . b p y]^{\mathrm{m}+}(\mathrm{RB} 3 \mathrm{M}$ YP/LANL2DZp).

\begin{tabular}{llll} 
metal ions & $\Delta E_{\text {tot }}$ & $\Delta \mathrm{ZPE}$ & $\begin{array}{l}\text { complexation } \\
\text { energy }\end{array}$ \\
\hline $\mathrm{Li}^{+}$ & 8.6 & -6.2 & 2.4 \\
$\mathrm{Na}^{+}$ & -3.7 & -5.2 & -8.9 \\
$\mathrm{~K}^{+}$ & -8.9 & -5.3 & -14.2 \\
$\mathrm{Rb}^{+}$ & -1.2 & -5.5 & -6.7 \\
$\mathrm{Cs}^{+}$ & 13.2 & -5.1 & 8.1 \\
$\mathrm{Be}^{2+}$ & -20.0 & -11.1 & -31.1 \\
$\mathrm{Be}^{2+}\left(C_{1}\right)$ & -33.5 & -10.4 & -43.9 \\
$\mathrm{Mg}^{2+}$ & -16.4 & -9.5 & -25.9 \\
$\mathrm{Mg}^{2+}\left(C_{1}\right)$ & -20.0 & -9.4 & -29.4 \\
$\mathrm{Ca}^{2+}$ & -36.4 & -8.7 & -45.1 \\
$\mathrm{Sr}^{2+}$ & -38.2 & -8.2 & -46.4 \\
$\mathrm{Ba}^{2+}$ & -36.2 & -7.1 & -43.3 \\
$\mathrm{Al}^{3+}$ & -97.6 & -11.6 & -109.2 \\
$\mathrm{Ga}^{3+}$ & -111.0 & -10.9 & -121.9 \\
$\mathrm{In}^{3+}$ & -115.0 & -9.4 & -124.4 \\
$\mathrm{Tl}^{3+}$ & -150.1 & -8.0 & -158.1
\end{tabular}
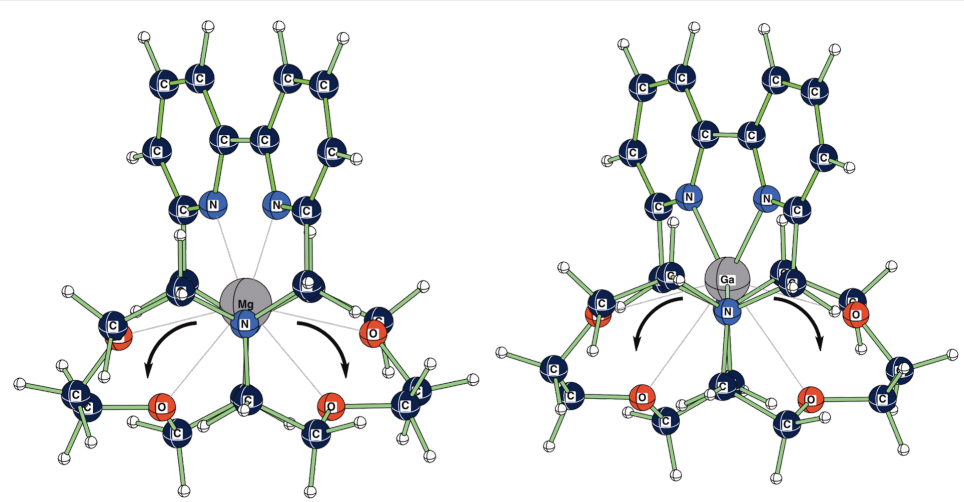

Figure 5: Calculated (RB3LYP/LANL2DZp) transition state structures $\left(C_{2}\right)$ for $[\mathrm{Mg} \subset 2.2 . b p y]^{2+}$ and $[\mathrm{Ga} \subset 2.2 . b p y]^{3+}$, showing the displacement vector for the imaginary frequency. 
hybridization state in both cases. Therefore, we will compare the distances obtained in this work against $\left[\mathrm{M}(\text { pyridine })_{n}\right]^{\mathrm{m}+}$ and $\left[\mathrm{M}\left(\mathrm{NH}_{3}\right)_{n}\right]^{\mathrm{m}+}\left(n=4\right.$ for $\mathrm{Li}^{+}$and $\mathrm{Be}^{2+}$ and 6 for all others), see Table 5, and against $\left[\mathrm{M}\left(\mathrm{H}_{2} \mathrm{O}\right)_{n}\right]^{\mathrm{m}+}\left(n=4\right.$ and 6 for $\mathrm{Li}^{+}$and $\mathrm{Be}^{2+}$ and 6 for all others), see Table 6 .

A direct comparison of the calculated data for the metal donor atom bonds in cryptates and for solvated metal ions is given in Table 7 for [2.2.bpy] and Table 8 for [2.bpy.bpy]. To illustrate the situation more clearly, the results are presented in Figure 6 and Figure 7 for [2.2.bpy] and in Figure 8 and Figure 9 for [2.bpy.bpy], where bisecting lines point to the cases in which coordination is most likely to occur. The ions above the line are somewhat too small, whereas the ions below the line are too large for the studied cryptand.

As depicted in Figure 6, the interaction of both $\mathrm{N}_{\mathrm{sp} 2}$ atoms of the bipyridine side of the [2.2.bpy] with all presented cations is essential. The bridgehead $\mathrm{N}_{\mathrm{sp} 3}$ atoms also play an important role for many of the studied ions, such as $\mathrm{Ga}^{3+}, \mathrm{Tl}^{3+}, \mathrm{In}^{3+}$, $\mathrm{Ca}^{2+}, \mathrm{Sr}^{2+}, \mathrm{K}^{+}, \mathrm{Ba}^{2+}$ and $\mathrm{Rb}^{+}$. However, for the larger $\left(\mathrm{Na}^{+}\right.$, $\left.\mathrm{Cs}^{+}\right)$and especially for the smaller ions $\left(\mathrm{Mg}^{2+}, \mathrm{Al}^{3+}, \mathrm{Li}^{+}\right)$, the $\mathrm{N}_{\mathrm{sp} 3}-\mathrm{M}^{\mathrm{m}+}$ interaction seems to be of lesser importance. The structure of $[\mathrm{Be} \subset 2.2 . \mathrm{bpy}]^{2+}$ presents a special case: in the energetically more stable $C_{1}$ symmetry (compared with $C_{2}$, see later discussion), the $\mathrm{Be}^{2+}$ ion seems to be shifted towards one of the $\mathrm{N}_{\mathrm{sp} 3}$ atoms, as the calculated bond lengths differ significantly. Its fourth coordination site is occupied by one of the oxygen donor atoms.

The data set describing the interaction of oxygen donor atoms with the studied ions is shown in Figure 7. Only three cations

\begin{tabular}{|c|c|c|}
\hline complex & $\mathrm{M}-\mathrm{O}[\AA]]$ & symmetry \\
\hline $\begin{array}{l}{ }^{a}\left[\mathrm{Li}\left(\mathrm{H}_{2} \mathrm{O}\right)_{6}\right]^{+} \\
{\left[\mathrm{Li}\left(\mathrm{H}_{2} \mathrm{O}\right)_{4}\right]^{+}}\end{array}$ & $\begin{array}{l}2.11 \\
1.95\end{array}$ & $\begin{array}{l}T_{h} \\
C_{2}\end{array}$ \\
\hline${ }^{\mathrm{b}}\left[\mathrm{Na}\left(\mathrm{H}_{2} \mathrm{O}\right)_{6}\right]^{+}$ & 2.40 & $T_{h}$ \\
\hline$\left[\mathrm{K}\left(\mathrm{H}_{2} \mathrm{O}\right)_{6}\right]^{+}$ & 2.76 & $T_{h}$ \\
\hline$\left[\mathrm{Rb}\left(\mathrm{H}_{2} \mathrm{O}\right)_{6}\right]^{+}$ & 2.97 & $T_{h}$ \\
\hline$\left[\mathrm{Cs}\left(\mathrm{H}_{2} \mathrm{O}\right)_{6}\right]^{+}$ & 3.20 & $T_{h}$ \\
\hline $\begin{array}{l}{\left[\mathrm{Be}\left(\mathrm{H}_{2} \mathrm{O}\right)_{6}\right]_{4}^{2+}} \\
{\left[\mathrm{Be}\left(\mathrm{H}_{2} \mathrm{O}\right)_{4}\right]^{2+}}\end{array}$ & $\begin{array}{l}1.85 \\
1.65\end{array}$ & $\begin{array}{l}T_{h} \\
C_{2}\end{array}$ \\
\hline$\left[\mathrm{Mg}\left(\mathrm{H}_{2} \mathrm{O}\right)_{6}\right]^{2+}$ & 2.10 & $T_{h}$ \\
\hline$\left[\mathrm{Ca}\left(\mathrm{H}_{2} \mathrm{O}\right)_{6}\right]^{2+}$ & 2.43 & $T_{h}$ \\
\hline$\left[\mathrm{Sr}\left(\mathrm{H}_{2} \mathrm{O}\right)_{6}\right]^{2+}$ & 2.60 & $T_{h}$ \\
\hline$\left[\mathrm{Ba}\left(\mathrm{H}_{2} \mathrm{O}\right)_{6}\right]^{2+}$ & 2.80 & $T_{h}$ \\
\hline$\left[\mathrm{Al}\left(\mathrm{H}_{2} \mathrm{O}\right)_{6}\right]^{3+}$ & 1.96 & $T_{h}$ \\
\hline$\left[\mathrm{Ga}\left(\mathrm{H}_{2} \mathrm{O}\right)_{6}\right]^{3+}$ & 1.99 & $T_{h}$ \\
\hline$\left[\ln \left(\mathrm{H}_{2} \mathrm{O}\right)_{6}\right]^{3+}$ & 2.14 & $T_{h}$ \\
\hline$\left[\mathrm{TI}\left(\mathrm{H}_{2} \mathrm{O}\right)_{6}\right]^{3+}$ & 2.29 & $T_{h}$ \\
\hline
\end{tabular}

a,bsee [62].

lie on the bisecting line: the small $\mathrm{Be}^{2+}$ and the larger $\mathrm{Ba}^{2+}$ and $\mathrm{Rb}^{+}$, which is a good prerequisite for the coordination of the O-atoms to these cations. Further ions, such as $\mathrm{Al}^{3+}, \mathrm{Ca}^{2+}, \mathrm{Sr}^{2+}$, $\mathrm{K}^{+}$and $\mathrm{Cs}^{+}$, are placed near the line, indicating that the proximity to the O-donors and a possible interaction still play an important role.

In the $[\mathrm{Ga} \subset 2.2 . \mathrm{bpy}]^{3+(\mathrm{TS})}$ and $[\mathrm{Mg} \subset 2.2 . \mathrm{bpy}]^{2+(\mathrm{TS})}$ cryptates, metal ions oscillate between both aliphatic di-ether chains, viz. between their oxygen donor atoms. Hence, half of the data

\begin{tabular}{|c|c|c|c|c|c|}
\hline complex & $\mathrm{M}-\mathrm{N}[\AA]]$ & symmetry & complex & $\mathrm{M}-\mathrm{N}[\AA]]$ & symmetry \\
\hline 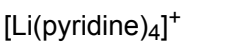 & 2.07 & $S_{4}$ & {$\left[\mathrm{Li}\left(\mathrm{NH}_{3}\right)_{4}\right]^{+}$} & 2.13 & $T$ \\
\hline$\left.[\mathrm{Na} \text { (pyridine) })_{6}\right]^{+}$ & 2.62 & $T_{h}$ & {$\left[\mathrm{Na}\left(\mathrm{NH}_{3}\right)_{6}\right]^{+}$} & 2.67 & $C_{2 h}$ \\
\hline 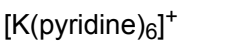 & 2.95 & $C_{i}$ & {$\left[\mathrm{~K}\left(\mathrm{NH}_{3}\right)_{6}\right]^{+}$} & 3.01 & $C_{2 h}$ \\
\hline$[\mathrm{Rb} \text { (pyridine) } 6]^{+}$ & 3.16 & $C_{i}$ & {$\left[\mathrm{Rb}\left(\mathrm{NH}_{3}\right)_{6}\right]^{+}$} & 3.21 & $C_{2 h}$ \\
\hline [Cs(pyridine) $\left._{6}\right]^{+}$ & 3.39 & $C_{i}$ & {$\left[\mathrm{Cs}\left(\mathrm{NH}_{3}\right)_{6}\right]^{+}$} & 3.45 & $C_{2 h}$ \\
\hline$\left.[\text { Be(pyridine })_{4}\right]^{2+}$ & 1.75 & $S_{4}$ & {$\left[\mathrm{Be}\left(\mathrm{NH}_{3}\right)_{4}\right]^{2+}$} & 1.77 & $T_{d}$ \\
\hline$\left.[\text { Mg(pyridine })_{6}\right]^{2+}$ & 2.31 & $T_{h}$ & {$\left[\mathrm{Mg}\left(\mathrm{NH}_{3}\right)_{6}\right]^{2+}$} & 2.29 & $C_{2 h}$ \\
\hline$\left[\mathrm{Ca}(\text { pyridine })_{6}\right]^{2+}$ & 2.61 & $T_{h}$ & {$\left[\mathrm{Ca}\left(\mathrm{NH}_{3}\right)_{6}\right]^{2+}$} & 2.63 & $C_{2 h}$ \\
\hline$\left[\operatorname{Sr}(\text { pyridine })_{6}\right]^{2+}$ & 2.75 & $T_{h}$ & {$\left[\mathrm{Sr}\left(\mathrm{NH}_{3}\right)_{6}\right]^{2+}$} & 2.80 & $C_{2 h}$ \\
\hline$\left[\mathrm{Ba}(\text { pyridine })_{6}\right]^{2+}$ & 2.95 & $C_{i}$ & {$\left[\mathrm{Ba}\left(\mathrm{NH}_{3}\right)_{6}\right]^{2+}$} & 3.00 & $C_{2 h}$ \\
\hline$\left[\mathrm{Al}(\text { pyridine })_{6}\right]^{3+}$ & 2.15 & $T_{h}$ & {$\left[\mathrm{Al}\left(\mathrm{NH}_{3}\right)_{6}\right]^{3+}$} & 2.12 & $C_{2}$ \\
\hline$\left[\mathrm{Ga}(\text { pyridine })_{6}\right]^{3+}$ & 2.18 & $T_{h}$ & {$\left[\mathrm{Ga}\left(\mathrm{NH}_{3}\right)_{6}\right]^{3+}$} & 2.15 & $C_{2}$ \\
\hline$\left[\ln (\text { pyridine })_{6}\right]^{3+}$ & 2.31 & $T_{h}$ & {$\left[\ln \left(\mathrm{NH}_{3}\right)_{6}\right]^{3+}$} & 2.31 & $C_{2}$ \\
\hline$\left[\mathrm{TI}(\text { pyridine })_{6}\right]^{3+}$ & 2.44 & $T_{h}$ & {$\left[\mathrm{TI}\left(\mathrm{NH}_{3}\right)_{6}\right]^{3+}$} & 2.46 & $C_{2}$ \\
\hline
\end{tabular}


Table 7: Comparison of the calculated distances (in $\AA$ ) of the metal-donor interactions in $[2.2 . b p y]$ with $\left[\mathrm{M}\left(\mathrm{pyridine}_{n}\right]^{\mathrm{m+}},\left[\mathrm{M}(\mathrm{NH})_{3}\right)^{\mathrm{m+}}\right.$ and $\left[\mathrm{M}\left(\mathrm{H}_{2} \mathrm{O}\right)_{n}\right]^{\mathrm{m+}}$ (point groups are given in parenthesis, for most metal cations $C_{2}$ symmetry is adopted).

\begin{tabular}{|c|c|c|c|c|c|c|}
\hline metal cation & $\mathrm{M}-\mathrm{N}_{\mathrm{sp} 2}$ & $\mathrm{M}-\mathrm{N}_{\text {pyridine }}$ & $\mathrm{M}-\mathrm{N}_{\mathrm{sp} 3}$ & $\mathrm{M}-\mathrm{NH}_{3}$ & $\mathrm{M}-\mathrm{O}$ & $\mathrm{M}-\mathrm{OH}_{2}$ \\
\hline $\mathrm{Li}^{+}\left(C_{1}\right)$ & $2.24,2.16$ & $2.07\left(S_{4}\right)$ & $2.58,2.87$ & $2.13(T)$ & $\begin{array}{l}3.19,3.01 \\
3.07,3.29\end{array}$ & $\begin{array}{l}1.95\left(C_{2}\right) \\
2.11\left(T_{h}\right)\end{array}$ \\
\hline $\mathrm{Li}^{+}$ & 2.19 & $2.07\left(S_{4}\right)$ & 2.71 & $2.13(T)$ & $3.15,3.12$ & $\begin{array}{l}1.95\left(C_{2}\right) \\
2.11\left(T_{h}\right)\end{array}$ \\
\hline $\mathrm{Na}^{+}$ & 2.79 & $2.62\left(T_{h}\right)$ & 2.90 & $2.67\left(C_{2 h}\right)$ & $2.84,2.81$ & $2.40\left(T_{h}\right)$ \\
\hline $\mathrm{K}^{+}$ & 2.95 & $2.95\left(C_{i}\right)$ & 3.03 & $3.01\left(C_{2 h}\right)$ & $2.89,2.84$ & $2.76\left(T_{h}\right)$ \\
\hline $\mathrm{Rb}^{+}$ & 3.02 & $3.16\left(C_{i}\right)$ & 3.07 & $3.21\left(C_{2 h}\right)$ & $2.94,2.92$ & $2.97\left(T_{h}\right)$ \\
\hline $\mathrm{Cs}^{+}$ & 3.12 & $3.39\left(C_{i}\right)$ & 3.12 & $3.45\left(C_{2 h}\right)$ & $3.02,3.03$ & $3.20\left(T_{h}\right)$ \\
\hline $\mathrm{Be}^{2+}\left(C_{1}\right)$ & $1.78,1.66$ & $1.75\left(S_{4}\right)$ & $1.83,3.64$ & $1.77\left(T_{d}\right)$ & $\begin{array}{l}1.65,3.76 \\
4.50,3.92\end{array}$ & $\begin{array}{l}1.65\left(C_{2}\right) \\
1.85\left(T_{h}\right)\end{array}$ \\
\hline $\mathrm{Be}^{2+}$ & 1.79 & $1.75\left(S_{4}\right)$ & 1.95 & $1.77\left(T_{d}\right)$ & $3.24,3.65$ & $\begin{array}{l}1.65\left(C_{2}\right) \\
1.85\left(T_{h}\right)\end{array}$ \\
\hline $\mathrm{Mg}^{2+}\left(C_{1}\right)$ & $2.24,2.23$ & $2.31\left(T_{h}\right)$ & $2.47,2.57$ & $2.29\left(C_{2 h}\right)$ & $\begin{array}{l}2.33,2.27 \\
3.42,3.45\end{array}$ & $2.10\left(T_{h}\right)$ \\
\hline $\mathrm{Mg}^{2+}$ (T.S.) & 2.29 & $2.31\left(T_{h}\right)$ & 2.48 & $2.29\left(C_{2 h}\right)$ & $2.71,2.74$ & $2.10\left(T_{h}\right)$ \\
\hline $\mathrm{Ca}^{2+}$ & 2.68 & $2.61\left(T_{h}\right)$ & 2.74 & $2.63\left(C_{2 h}\right)$ & $2.68,2.68$ & $2.43\left(T_{h}\right)$ \\
\hline $\mathrm{Sr}^{2+}$ & 2.81 & $2.75\left(T_{h}\right)$ & 2.87 & $2.80\left(C_{2 h}\right)$ & $2.77,2.76$ & $2.60\left(T_{h}\right)$ \\
\hline $\mathrm{Ba}^{2+}$ & 2.92 & $2.95\left(C_{i}\right)$ & 2.98 & $3.00\left(C_{2 h}\right)$ & $2.86,2.84$ & $2.80\left(T_{h}\right)$ \\
\hline $\mathrm{Al}^{3+}$ & 2.07 & $2.15\left(T_{h}\right)$ & 3.13 & $2.12\left(C_{2}\right)$ & $2.02,2.09$ & $1.96\left(T_{h}\right)$ \\
\hline $\mathrm{Ga}^{3+}\left(C_{1}\right)$ & $2.05,2.05$ & $2.18\left(T_{h}\right)$ & $2.22,2.20$ & $2.15\left(C_{2}\right)$ & $\begin{array}{l}2.11,2.16 \\
3.76,3.80\end{array}$ & $1.99\left(T_{h}\right)$ \\
\hline $\mathrm{Ga}^{3+}$ (T.S.) & 2.06 & $2.18\left(T_{h}\right)$ & 2.14 & $2.15\left(C_{2}\right)$ & $2.86,3.01$ & $1.99\left(T_{h}\right)$ \\
\hline $\ln ^{3+}$ & 2.31 & $2.31\left(T_{h}\right)$ & 2.48 & $2.31\left(C_{2}\right)$ & $2.46,2,47$ & $2.14\left(T_{h}\right)$ \\
\hline $\mathrm{Tl}^{3+}$ & 2.48 & $2.44\left(T_{h}\right)$ & 2.55 & $2.46\left(C_{2}\right)$ & $2.71,2.73$ & $2.29\left(T_{h}\right)$ \\
\hline
\end{tabular}

Table 8: Comparison of the calculated distances (in $\AA$ ) of the metal-donor interactions in [2.bpy.bpy] with $\left[\mathrm{M}\left(\mathrm{pyridine}_{n}\right]^{\mathrm{m}+},\left[\mathrm{M}(\mathrm{NH})_{3}\right)^{\mathrm{m+}}\right.$ and $\left[\mathrm{M}\left(\mathrm{H}_{2} \mathrm{O}\right)_{n}\right]^{\mathrm{m+}}$ (point groups are given in parenthesis, for most metal cations $C_{2}$ symmetry is adopted).

\begin{tabular}{|c|c|c|c|c|c|c|}
\hline metal cation & $\mathrm{M}-\mathrm{N}_{\mathrm{sp} 2}$ & $\mathrm{M}-\mathrm{N}_{\text {pyridine }}$ & $\mathrm{M}-\mathrm{N}_{\mathrm{sp} 3}$ & $\mathrm{M}-\mathrm{NH}_{3}$ & $\mathrm{M}-\mathrm{O}$ & $\mathrm{M}-\mathrm{OH}_{2}$ \\
\hline $\mathrm{Li}^{+}$ & $2.37,2.44$ & $2.07\left(S_{4}\right)$ & 2.82 & $2.13(T)$ & 3.42 & $\begin{array}{l}1.95\left(C_{2}\right) \\
2.11\left(T_{h}\right)\end{array}$ \\
\hline $\mathrm{Na}^{+}$ & $2.78,2.79$ & $2.62\left(T_{h}\right)$ & 2.84 & $2.67\left(C_{2 h}\right)$ & 2.89 & $2.40\left(T_{h}\right)$ \\
\hline $\mathrm{K}^{+}$ & $2.91,2.93$ & $2.95\left(C_{i}\right)$ & 2.96 & $3.01\left(C_{2 h}\right)$ & 2.84 & $2.76\left(T_{h}\right)$ \\
\hline $\mathrm{Rb}^{+}$ & $2.98,3.00$ & $3.16\left(C_{i}\right)$ & 3.04 & $3.21\left(C_{2 h}\right)$ & 2.90 & $2.97\left(T_{h}\right)$ \\
\hline $\mathrm{Cs}^{+}$ & $3.08,3.09$ & $3.39\left(C_{i}\right)$ & 3.11 & $3.45\left(C_{2 h}\right)$ & 2.98 & $3.20\left(T_{h}\right)$ \\
\hline $\mathrm{Be}^{2+}\left(C_{1}\right)$ & $\begin{array}{l}1.69,1.81 \\
1.77,3.25\end{array}$ & $1.75\left(S_{4}\right)$ & $1.90,4.48$ & $1.77\left(T_{d}\right)$ & $3.62,4.84$ & $\begin{array}{l}1.65\left(\mathrm{C}_{2}\right) \\
1.85\left(T_{h}\right)\end{array}$ \\
\hline $\mathrm{Be}^{2+}$ & $1.82,1.89$ & $1.75\left(S_{4}\right)$ & 2.92 & $1.77\left(T_{d}\right)$ & 4.17 & $\begin{array}{l}1.65\left(C_{2}\right) \\
1.85\left(T_{h}\right)\end{array}$ \\
\hline $\mathrm{Mg}^{2+}\left(C_{1}\right)$ & $\begin{array}{l}2.41,2.32 \\
2.34,2.50\end{array}$ & $2.31\left(T_{h}\right)$ & $2.97,2.62$ & $2.29\left(C_{2 h}\right)$ & $2.31,2.55$ & $2.10\left(T_{h}\right)$ \\
\hline $\mathrm{Mg}^{2+}$ & $2.28,2.33$ & $2.31\left(T_{h}\right)$ & 2.65 & $2.29\left(C_{2 h}\right)$ & 2.34 & $2.10\left(T_{h}\right)$ \\
\hline $\mathrm{Ca}^{2+}$ & $2.69,2.70$ & $2.61\left(T_{h}\right)$ & 2.75 & $2.63\left(C_{2 h}\right)$ & 2.69 & $2.43\left(T_{h}\right)$ \\
\hline $\mathrm{Sr}^{2+}$ & $2.81,2.82$ & $2.75\left(T_{h}\right)$ & 2.84 & $2.80\left(C_{2 h}\right)$ & 2.77 & $2.60\left(T_{h}\right)$ \\
\hline $\mathrm{Ba}^{2+}$ & $2.91,2.92$ & $2.95\left(C_{i}\right)$ & 2.96 & $3.00\left(C_{2 h}\right)$ & 2.84 & $2.80\left(T_{h}\right)$ \\
\hline $\mathrm{Al}^{3+}$ & $2.04,2.08$ & $2.15\left(T_{h}\right)$ & 2.34 & $2.12\left(C_{2}\right)$ & 3.83 & $1.96\left(T_{h}\right)$ \\
\hline $\mathrm{Ga}^{3+}$ & $2.07,2.12$ & $2.18\left(T_{h}\right)$ & 2.42 & $2.15\left(C_{2}\right)$ & 3.77 & $1.99\left(T_{h}\right)$ \\
\hline $\ln ^{3+}$ & $2.34,2.37$ & $2.31\left(T_{h}\right)$ & 2.64 & $2.31\left(C_{2}\right)$ & 2.56 & $2.14\left(T_{h}\right)$ \\
\hline $\mathrm{Tl}^{3+}$ & $2.51,2.53$ & $2.44\left(T_{h}\right)$ & 2.65 & $2.46\left(C_{2}\right)$ & 2.82 & $2.29\left(T_{h}\right)$ \\
\hline
\end{tabular}



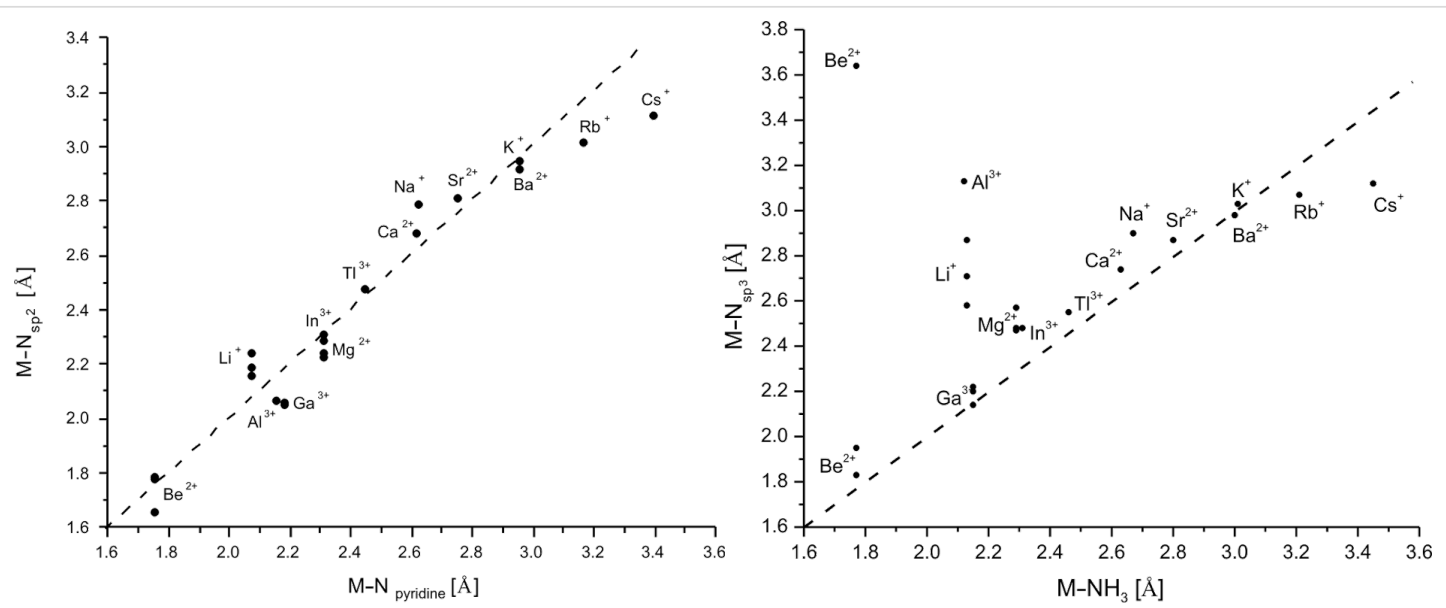

Figure 6: Comparison of the calculated (RB3LYP/LANL2DZp) $M-N_{\text {pyridine }} / M-N_{s p 2}$ and $M-N_{3} / M-N_{s p 3}$ coordinating distances for [2.2.bpy] (dashed line: bisecting line; for the data see Table 7).

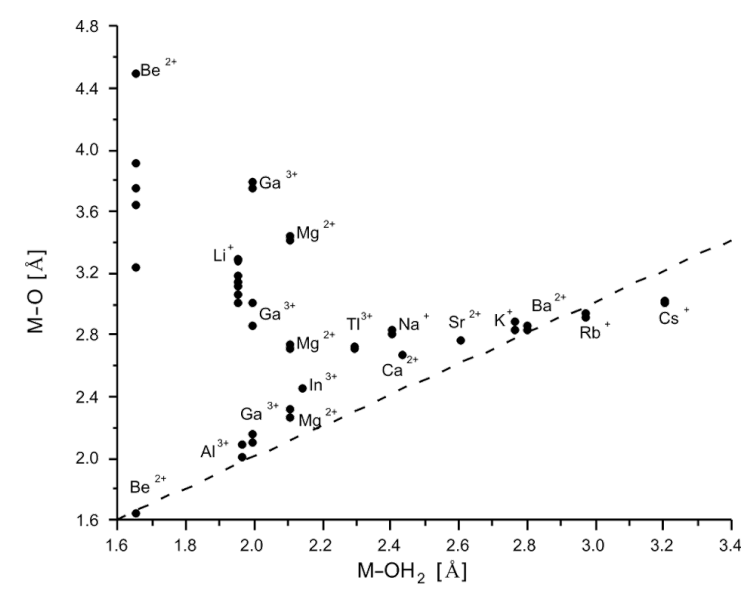

Figure 7: Comparison of the calculated (RB3LYP/LANL2DZp) $\mathrm{M}-\mathrm{OH}_{2}$ and $\mathrm{M}-\mathrm{O}$ coordinating distances for [2.2.bpy] (dashed line: bisecting line; for the data see Table 7).

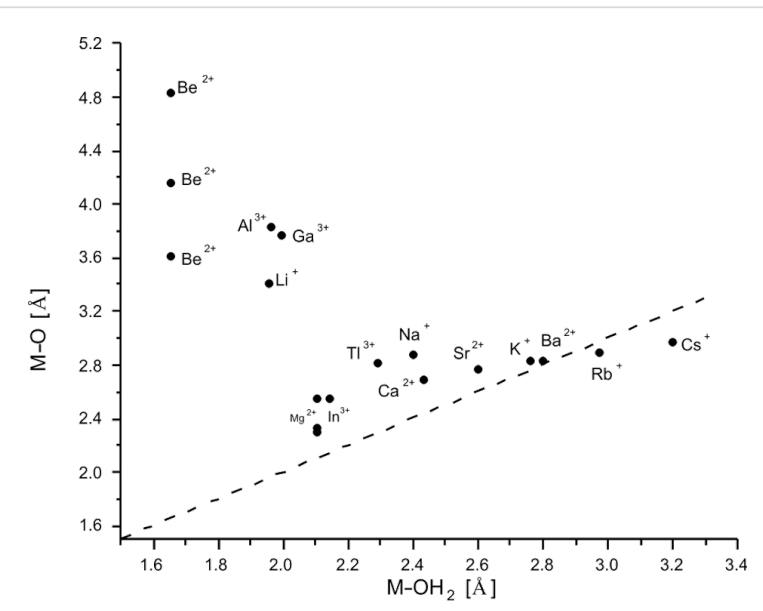

Figure 9: Comparison of the calculated (RB3LYP/LANL2DZp) $\mathrm{M}-\mathrm{OH}_{2}$ and $\mathrm{M}-\mathrm{O}$ coordinating distances for [2.bpy.bpy] (dashed line: bisecting line; for the data see Table 8).
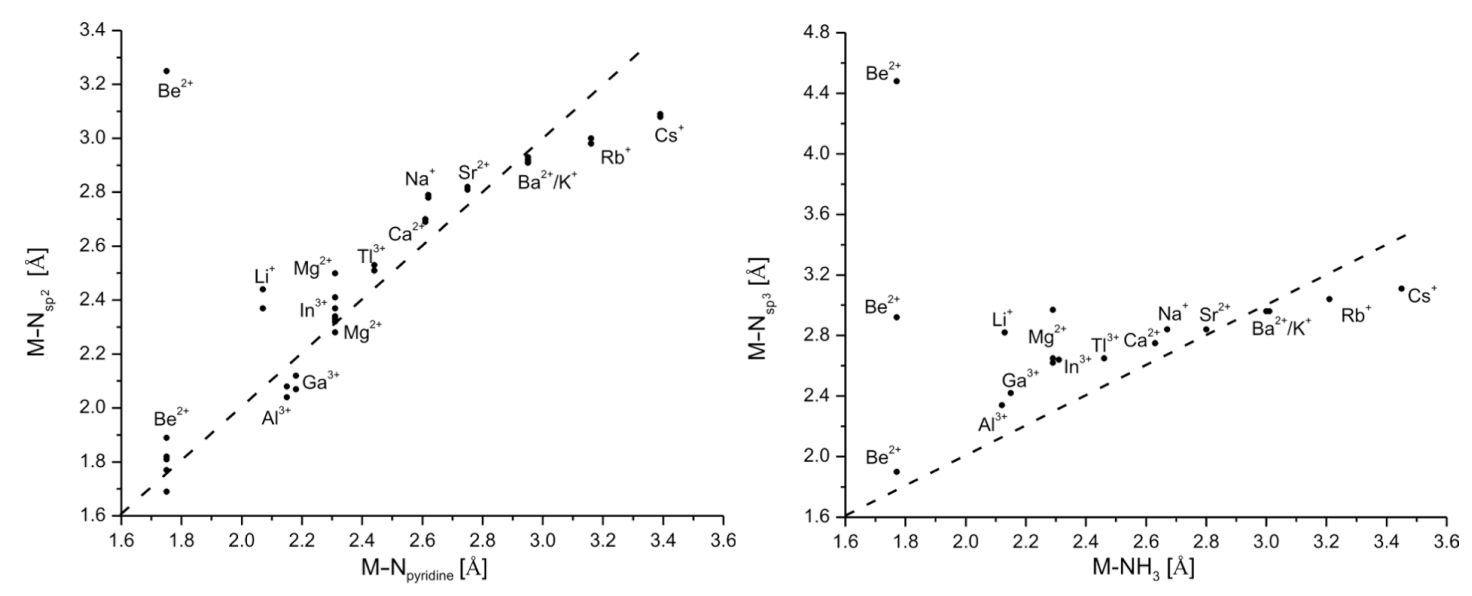

Figure 8: Comparison of the calculated (RB3LYP/LANL2DZp) $M-N_{\text {pyridine }} / M-N_{s p 2}$ and $M-N_{3} / M-N_{s p 3}$ coordinating distances for [2.bpy.bpy] (dashed line: bisecting line; for the data see Table 8). 
points for $\mathrm{Ga}^{3+}\left(C_{1}\right)$ and $\mathrm{Mg}^{2+}\left(C_{1}\right)$ also lie close to the bisecting line, pointing to possible coordination. Finally, $\mathrm{Li}^{+}, \mathrm{In}^{3+}, \mathrm{Tl}^{3+}$ and $\mathrm{Na}^{+}$as well as the residual data points for $\mathrm{Be}^{2+}, \mathrm{Ga}^{3+}$ and $\mathrm{Mg}^{2+}$ are positioned too far away from the line for the potential coordination to be relevant. At a first glance this finding seems to contradict the experimentally obtained results for $\mathrm{Na}^{+}$, but the solid-state structure of $[\mathrm{Na} \subset 2.2$.bpy] Br is somehow distorted (X-ray: $C_{1}$ symmetry compared to calculated $C_{2}$ ) [61], to allow the cationic sodium center to interact with the available cryptand donor atoms and to get a better stabilization as in the applied weakly coordinating solvent acetonitrile [63-65].

It can be concluded that an interaction between $\mathrm{Ca}^{2+}, \mathrm{Sr}^{2+}, \mathrm{K}^{+}$, $\mathrm{Ba}^{2+}$ and $\mathrm{Rb}^{+}$and all present donor atoms $\left(\mathrm{N}_{\mathrm{sp} 2}, \mathrm{~N}_{\mathrm{sp} 3}\right.$ and $\left.\mathrm{O}\right)$ plays an important role. This can be explained, since especially the larger $\mathrm{K}^{+}, \mathrm{Ba}^{2+}$ and $\mathrm{Rb}^{+}$ions prefer a higher coordination number than six [3]. They are also energetically favored (see further discussion) and seem to fit well into the cavity. $\mathrm{In}^{3+}$ and $\mathrm{Tl}^{3+}$ prefer the interaction with nitrogen donor atoms, completing the vacant positions with $\mathrm{O}$-atoms. Among the earth metal ions $\mathrm{Tl}^{3+}$ is also energetically favored (see further discussion). $\mathrm{Be}^{2+}$ has a special position among the cations as described above, but it is still too small for the cryptand, as are also $\mathrm{Li}^{+}, \mathrm{Mg}^{2+}, \mathrm{Al}^{3+}$ and $\mathrm{Ga}^{3+}$. For $\mathrm{Na}^{+}$and $\mathrm{Cs}^{+}$, the interaction with the bridgehead nitrogen appears not to be essential, more important are the connections to nitrogen atoms of the bipyridine side of the ligand and oxygen donor atoms. These cations also do not fit well into the cavity, being too small or too large, respectively.

As can be seen from Figure 8, the interaction with $\mathrm{N}_{\mathrm{sp} 2}$ atoms of the bipyridine site of [2.bpy.bpy] is significant for all studied ions, though the largest $\left(\mathrm{Rb}^{+}, \mathrm{Cs}^{+}\right)$deviate slightly from the general trend. A similar situation occurs for the bridgehead nitrogen atoms: most of the investigated cations are placed along the bisecting line, indicating an important role of the potential coordination. The large $\left(\mathrm{Rb}^{+}, \mathrm{Cs}^{+}\right)$and small $\left(\mathrm{Li}^{+}\right.$, $\left.\mathrm{Mg}^{2+}\left(C_{1}\right)\right)$ ions lie further away from the line, as this kind of interaction is less relevant for them. $\mathrm{Be}^{2+}$ again presents a special case, as it is shifted towards one of the $\mathrm{N}_{\mathrm{sp} 3}$ donor atoms and coordinates furthermore to three of the $\mathrm{N}_{\mathrm{sp} 2}$ atoms.

The interaction between oxygen donor atoms and the studied cations is less important in the case of [2.bpy.bpy], as there are six nitrogen donor atoms present to fill the coordination sphere. Even so, the bridgehead nitrogens are in some cases too far away for an effective interaction. As shown in Figure 9, only $\mathrm{K}^{+}, \mathrm{Ba}^{2+}$ and $\mathrm{Rb}^{+}$lie on the bisecting line, while $\mathrm{Mg}^{2+}, \mathrm{Ca}^{2+}$, $\mathrm{Sr}^{2+}$ and $\mathrm{Cs}^{+}$are placed near it. The residual cations, especially the small $\mathrm{Be}^{2+}, \mathrm{Li}^{+}, \mathrm{Al}^{3+}$ and $\mathrm{Ga}^{3+}$ are too far away for any kind of significant interaction.
Summing up, $\mathrm{Ca}^{2+}, \mathrm{Sr}^{2+}, \mathrm{K}^{+}, \mathrm{Ba}^{2+}$ and $\mathrm{Rb}^{+}$fit best into the cavity of [2.bpy.bpy], as was the case for [2.2.bpy], though the smaller cations $\left(\mathrm{Ca}^{2+}\right.$ and $\left.\mathrm{Sr}^{2+}\right)$ prefer the interaction with the nitrogen donor atoms and the larger cations $\left(\mathrm{K}^{+}, \mathrm{Ba}^{2+}\right.$ and $\left.\mathrm{Rb}^{+}\right)$ tend to interact with the oxygen donors. The smaller cations are nested against the nitrogen atoms, though they do not fit well into the cavity. Among the earth metal ions, $\mathrm{In}^{3+}$ fits best, lying closer to the nitrogen donors and being also one of the energetically favored cations (Table 4).

According to the performed comparison of the bond lengths between metal cations and N/O donor atoms in cryptates with the same bond lengths of the solvated metal centers, both cavities have a size similar to [2.2.2] and prefer cations with larger radii in every one of the studied main groups. However, an additional energy consideration is necessary to provide detailed and more precise information about the favorable coordination layout of the investigated cryptands.

Besides the structural evaluation of the computed systems, the examination of the energy of a model reaction, depicted in Scheme 1, provides valuable results, important for the prediction of the cryptand's selectivity. All cations were calculated in the six-fold coordination environment, to maintain equal conditions for all studied systems. For the lithium [66] and beryllium [67] cations the preferable four-fold coordinated structures were found. They show additional water molecules, which do not interact directly with the metal center, but are held in the second coordination sphere by hydrogen bonds. However, the gas phase $\left[\mathrm{Li}\left(\mathrm{H}_{2} \mathrm{O}\right)_{6}\right]^{+}$and $\left[\mathrm{Be}\left(\mathrm{H}_{2} \mathrm{O}\right)_{6}\right]^{2+}$ exist as local minima. The complexation energies computed in this way are shown in Table 3 and Table 4, and are plotted against the ionic radii, see Figure 10 and Figure 11.

$$
\left[\mathrm{M}\left(\mathrm{H}_{2} \mathrm{O}\right)_{6}\right]^{\mathrm{m+}}+\text { cryptand } \longrightarrow[\mathrm{M} \subset \text { cryptand }]^{\mathrm{m+}}+6 \mathrm{H}_{2} \mathrm{O}
$$

cryptand: [2.2.bpy], [2.bpy.bpy]

\section{Scheme 1: Model reaction}

The first and second places in the stability order of the endohedral complexes of [2.2.bpy] with the studied alkali metal ions are occupied by $[\mathrm{K} \subset 2 \text { 2.2.bpy }]^{+}$and $[\mathrm{Rb} \subset 2.2 . \mathrm{bpy}]^{+}$. Among the examined alkaline earth ions the cryptates with $\mathrm{Sr}^{2+}$ and $\mathrm{Ba}^{2+}$ are the most stable and show an equal stability level. In the case of earth metal ions the most stable complex is formed for $\mathrm{Tl}^{3+}$, and this is in line with the high $\log K_{1}(9.4)$ of $\mathrm{Tl}^{3+}$ to form $[\mathrm{Tl}(\mathrm{bpy})]^{3+}[68,69]$. Cryptand [2.bpy.bpy] also prefers to bind $\mathrm{K}^{+}$, this time followed by $\mathrm{Na}^{+}$; and $\mathrm{Sr}^{2+}$, followed by $\mathrm{Ca}^{2+}$. Finally the combination with $\mathrm{Tl}^{3+}$ yields the most stable 


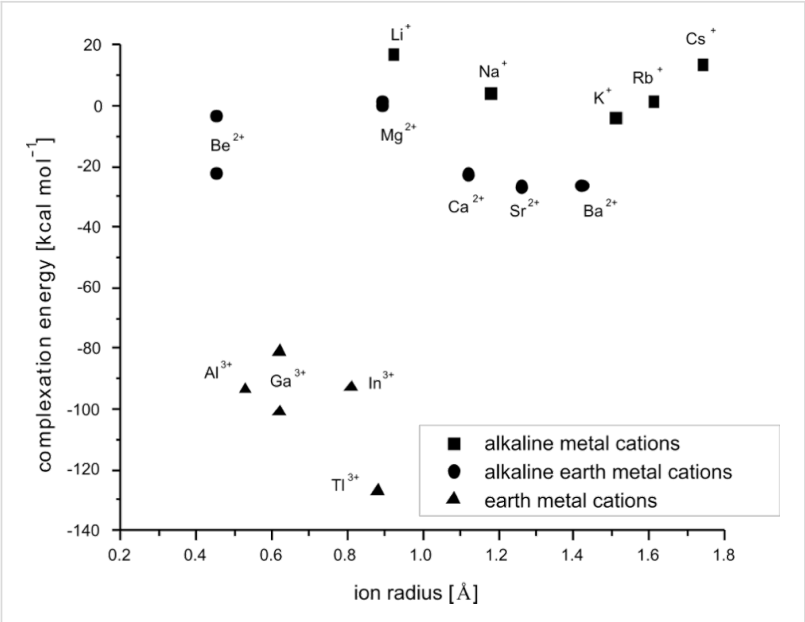

Figure 10: RB3LYP/LANL2DZp complexation energies for $[\mathrm{M} \subset 2 \text { 2.2.bpy }]^{\mathrm{m}+}$ according to Scheme 1, plotted against the ionic radius of $\mathrm{M}^{\mathrm{m+}}$; for the data see Table 3 .

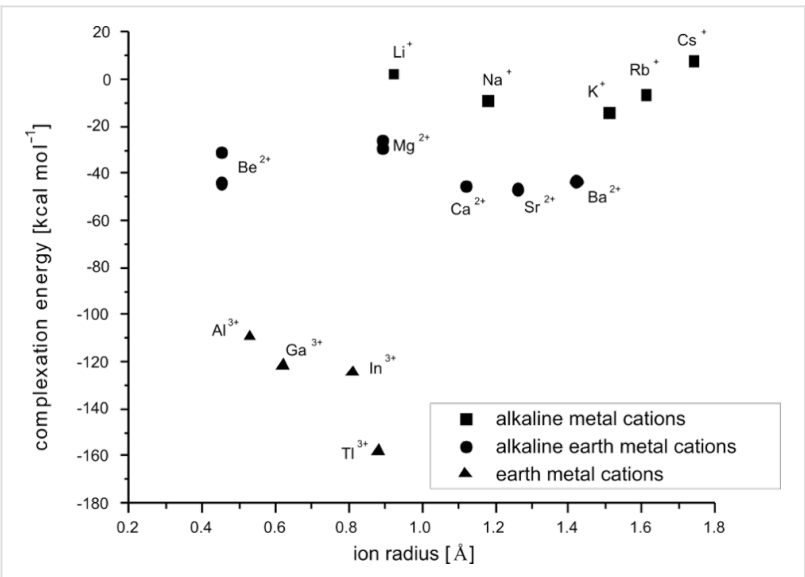

Figure 11: RB3LYP/LANL2DZp complexation energies for $[\mathrm{M} \subset 2 \text {.bpy.bpy }]^{\mathrm{m}+}$ according to Scheme 1, plotted against the ionic radius of $\mathrm{M}^{\mathrm{m}+}$; for the data see Table 4 .

cryptate. In general, the computed energies confirm our conclusions drawn from the bond lengths between the metal centers and donor atoms of the cryptands and/or solvent molecules. Both ligands [2.2.bpy] and [2.bpy.bpy] favor larger cations, indicating their large cavity size. A comparison of the preferred ion selectivity with the earlier reported results [2] demonstrates that both cryptands investigated in this work exhibit a hole size similar to that of [2.2.2], although [2.2.bpy] is somewhat larger than [2.bpy.bpy], which can be explained since the (bpy) part of the ligand is sterically more restrained and as a result the cryptand with two of them does not open up for larger guests.

The positive complexation energy for [Cs $\subset 2$.bpy.bpy $]^{+}$, indicates that the $\mathrm{Cs}^{+}$cation is too large for the cryptand cavity, while the positive energy value for $[\mathrm{Li} \subset 2 . \mathrm{bpy} . \mathrm{bpy}]^{+}$, is a sign that the smallest alkali cation cannot be stabilized sufficiently.
However, both values fit nicely in the trend. For all other ions studied here, the complexation with [2.bpy.bpy] results in negative stabilization energies.

In the case of [2.2.bpy], $\mathrm{K}^{+}$is the only alkali cation for which complexation by the cryptand results in a negative stabilization energy, though the values for $[\mathrm{Rb} \subset 2.2 . \mathrm{bpy}]^{+}$and $[\mathrm{Na} \subset 2.2 . \mathrm{bpy}]^{+}$are very close, indicating ready coordination by the cryptand. The formation of cryptates with alkaline-earth and earth metal ions is again characterized by a negative stabilization energy, with the exception of $[\mathrm{Mg} \subset 2.2 . b p y]^{2+(T S)}$. The $\mathrm{Be}^{2+}$ ion presents a clear exception in both plots. As already mentioned, the beryllium dications are fourfold coordinated. In the case of $[\mathrm{Be} \subset 2.2 . \mathrm{bpy}]^{2+}$, the structure with $C_{1}$ symmetry is energetically more stable $(-22.0 \mathrm{kcal} / \mathrm{mol})$ than the one with $C_{2}$ symmetry $(-3.1 \mathrm{kcal} / \mathrm{mol})$. The beryllium ion is here coordinated by two $\mathrm{N}_{\mathrm{sp} 2}$, one $\mathrm{N}_{\mathrm{sp} 3}$ bridgehead and one $\mathrm{O}$ donor atom, so that an approximate tetrahedral coordination sphere with somewhat altered bonds (1.66 $\AA, 1.78 \AA, 1.83 \AA$ and $1.65 \AA$ ) compared to $\left[\mathrm{Be}(\text { pyridine })_{4}\right]^{2+}(1.75 \AA)$, $\left[\mathrm{Be}\left(\mathrm{NH}_{3}\right)_{4}\right]^{2+}(1.77 \AA)$ and $\left[\mathrm{Be}\left(\mathrm{OH}_{2}\right)\right]^{2+}(1.65 \AA)$ is formed. In the case of [Be $\subset 2$.bpy.bpy], the structure with $C_{1}$ symmetry is favored again, though the difference in energy is not as large $(-43.9 \mathrm{kcal} / \mathrm{mol}$ compared to $-31.1 \mathrm{kcal} / \mathrm{mol})$. The coordination of $\mathrm{Be}^{2+}$ in $[\mathrm{Be} \subset 2 \text {.bpy.bpy }]^{2+}$ is somewhat different, with the coordination sphere formed by three $\mathrm{N}_{\mathrm{sp} 2}$ and one $\mathrm{N}_{\mathrm{sp} 3}$ bridgehead donor atom. The bonds are further elongated compared to $[\mathrm{Be} \subset 2.2 \text {.bpy }]^{2+}$ and result in a distorted tetrahedron. Therefore, $[\mathrm{Be} \subset 2 \text { 2.2.bpy }]^{2+}$ and $[\mathrm{Be} \subset 2 \text { 2.bpy.bpy }]^{2+}$ can be considered as structures allowing appropriate coordination and stabilization in the gas phase, but in solution these structures will surely not be superior to solvated $\mathrm{Be}^{2+}$ and an empty cryptand. In general, the computed complexation energies allow conclusions about the stability order of the endohedral cryptate complexes and correlated with it about the ion selectivity of the respective cryptands, as will be explained below.

Earlier reports from our [1-4] and other [70] groups demonstrated that the cryptand does not remain unaltered throughout the complexation process; it twists in order to adjust for the optimal interaction with the metal cation. The effect of this twisting is observable also in the experimentally achieved solidstate structures. For example, [phen.phen.phen] has a very rigid structure, so the resulting average bond length between the metal center and the aromatic nitrogen donor atoms in $[\mathrm{Na} \subset \text { phen.phen.phen }]^{+}$are longer than the equivalent bonds in $[\mathrm{Na} \subset 2.2 . \mathrm{bpy}]^{+}\left(\mathrm{av} \mathrm{N} \mathrm{N}_{\mathrm{sp} 2}-\mathrm{Na}=2.70 \AA[71]\right.$ and av $\mathrm{N}_{\mathrm{sp} 2}-\mathrm{Na}=$ $2.61 \AA[61]$, respectively). The [2.2.bpy] cryptand has namely two glycol-containing molecular arms, which can wrap flexibly around the cation, allowing closer proximity between the metal center and bipyridine ligand. 
The increasing size of the guest ions is accompanied by a general enlargement of the metal-donor bond length, as can be concluded from the elucidation of the calculated distances (see Table 1 and Table 2). Apart from various contributions of the guest ions, the observed behavior is evidence for the possible flexibility of the studied cryptands. A proper flexibility requires an adaptable molecular moiety.

While $[\mathrm{M} \subset 2.2 . \mathrm{bpy}]^{\mathrm{m}+}$ has one molecular bar with $\mathrm{N}-\mathrm{CH}_{2}$ (pyridine) motifs adjacent to the $\mathrm{N}$ bridgeheads and a conformationally nearly unhampered $\mathrm{C}-\mathrm{C}$ bond bridging the two pyridine rings and two molecular bars $\mathrm{C}_{2} \mathrm{H}_{4}-\mathrm{O}-\mathrm{C}_{2} \mathrm{H}_{4}-\mathrm{O}-\mathrm{C}_{2} \mathrm{H}_{4}$ adjacent to the $\mathrm{N}$ bridgehead atoms, the $[\mathrm{M} \subset 2 \text { 2.bpy.bpy }]^{\mathrm{m}+}$ has two of the bipyridine and one of the glycol building blocks. Descriptors for the twist and tilt of these moieties are the torsion angles such as $\mathrm{CH}_{2}-\mathrm{N}_{\mathrm{sp} 3}-\mathrm{N}_{\mathrm{sp} 3}-\mathrm{CH}_{2}$, $\mathrm{N}_{\mathrm{sp} 2}-\mathrm{C}-\mathrm{C}-\mathrm{N}_{\mathrm{sp} 2},\left(\mathrm{CH}_{2}\right)_{2}-\mathrm{N}_{\mathrm{sp} 3}-\mathrm{N}_{\mathrm{sp} 3}-\left(\mathrm{CH}_{2}\right)_{2}$ and $\mathrm{O}-\mathrm{C}-\mathrm{C}-\mathrm{O}$. They all show a qualitative linear behavior that mainly depends on the size of the ion, see Figure 12, Figure 13 and Figure 14. The torsion angles $\mathrm{CH}_{2}-\mathrm{N}_{\mathrm{sp} 3}-\mathrm{N}_{\mathrm{sp} 3}-\mathrm{CH}_{2}$ and $\left(\mathrm{CH}_{2}\right)_{2}-\mathrm{N}_{\mathrm{sp} 3}-\mathrm{N}_{\mathrm{sp} 3}-\left(\mathrm{CH}_{2}\right)_{2}$ show very similar behavior, becoming more positive within the studied main groups, with the only exception presented by the earth metals, whose values are slightly scattered but still fit well in the general trend, see Figure 12. These angles cover the widest range in both host-guest systems, see Table 9.

The illustrated occurrence evidences the importance of the possible alteration of the angles between the $\mathrm{CH}_{2}$ groups and the $\mathrm{N}_{\mathrm{sp} 3}$ bridgehead for optimal matching between the host and the guest molecules. The stereochemistry of all investigated cryptates is the same and can be described as $\lambda$, as the

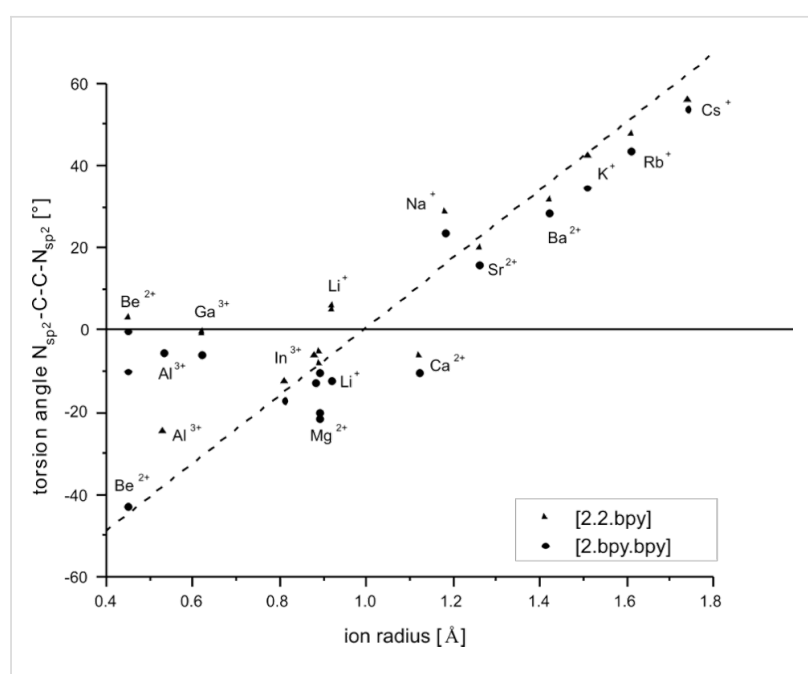

Figure 13: RB3LYP/LANL2DZp torsion angle $\mathrm{N}_{\mathrm{sp2}}-\mathrm{C}-\mathrm{C}-\mathrm{N}_{\mathrm{sp} 2}$ for $[\mathrm{M} \subset \text { 2.2.bpy }]^{\mathrm{m+}}$ and $[\mathrm{M} \subset 2 . \mathrm{bpy} \cdot \mathrm{bpy}]^{\mathrm{m+}}$ plotted against the ionic radius of $\mathrm{M}^{\mathrm{m}+}$ (dashed line represents the observed trend).

pointed angles are negative [3]. The only exception is the $\left(\mathrm{CH}_{2}\right)_{2}-\mathrm{N}_{\mathrm{sp} 3}-\mathrm{N}_{\mathrm{sp} 3}-\left(\mathrm{CH}_{2}\right)_{2}$ angle in $[\mathrm{Mg} \subset 2.2 . \mathrm{bpy}]^{2+(\mathrm{TS})}$.

The $\mathrm{N}_{\mathrm{sp} 2}-\mathrm{C}-\mathrm{C}-\mathrm{N}_{\mathrm{sp} 2}$ torsion angle covers a somewhat smaller range than both angles at the bridgehead nitrogen atoms, as shown in Table 9, because of the greater rigidity of the connected pyridine rings compared to the aliphatic $\mathrm{CH}_{2}$ groups. However, the differences are much larger than in the case of $[\mathrm{M} \subset \text { 2.2.phen }]^{\mathrm{m}+}$ and $[\mathrm{M} \subset 2 \text { 2.phen.phen }]^{\mathrm{m}+}[1]$, which is easy to understand since the polycyclic heteroaromatic phenantroline system is inflexible, while the conformationally nearly unhampered $\mathrm{C}-\mathrm{C}$ bond bridging the two pyridine moieties allows more flexible arrangement of host and guest. The main
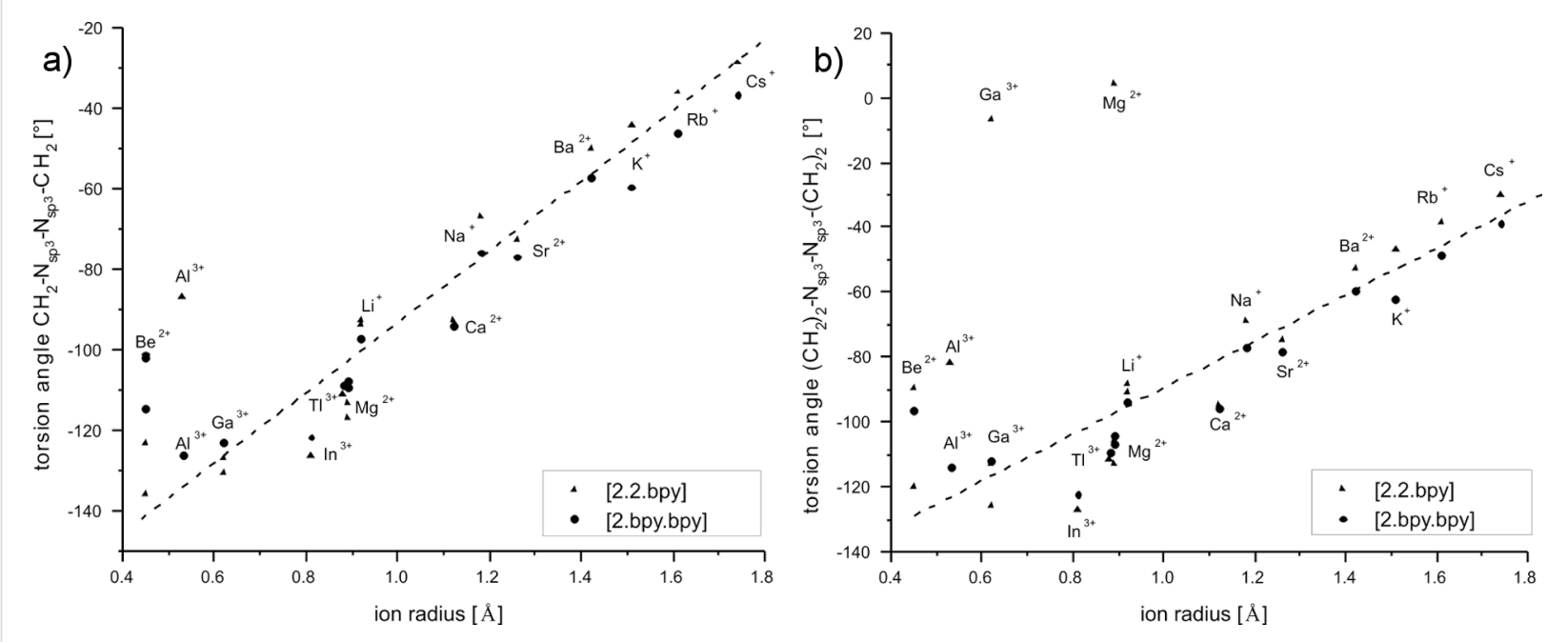

Figure 12: RB3LYP/LANL2DZp torsion angles $\mathrm{CH}_{2}-\mathrm{N}_{\mathrm{sp} 3}-\mathrm{N}_{\mathrm{sp} 3}-\mathrm{CH}_{2}$ (a) and $\left(\mathrm{CH}_{2}\right)_{2}-\mathrm{N}_{\mathrm{sp} 3}-\mathrm{N}_{\mathrm{sp} 3}-\left(\mathrm{CH}_{2}\right)_{2}$ (b) for $\left[\mathrm{M} \subset 2.2\right.$.bpy] ${ }^{\mathrm{m}+}$ and $[\mathrm{M} \subset 2 \text {.bpy.bpy }]^{\mathrm{m}+}$ plotted against the ionic radius of $\mathrm{M}^{\mathrm{m}+}$ (dashed line represents the observed trend). 
Table 9: (Maximum) range of the calculated torsion angles.

\begin{tabular}{lllll} 
& $\mathrm{CH}_{2}-\mathrm{N}_{\mathrm{sp} 3}-\mathrm{N}_{\mathrm{sp} 3}-\mathrm{CH}_{2}$ & $\left(\mathrm{CH}_{2}\right)_{2}-\mathrm{N}_{\mathrm{sp} 3}-\mathrm{N}_{\mathrm{sp} 3}-\left(\mathrm{CH}_{2}\right)_{2}$ & $\mathrm{~N}_{\mathrm{sp} 2}-\mathrm{C}-\mathrm{C}-\mathrm{N}$ sp2 & $\mathrm{O}-\mathrm{C}-\mathrm{C}-\mathrm{O}$ \\
\hline [2.2.bpy] & $101.2^{\circ}$ & $96.9^{\circ}$ & $80.5^{\circ}$ & $35.9^{\circ}$ \\
{$[$ 2.bpy.bpy] } & $89.4^{\circ}$ & $83.9^{\circ}$ & $71.5^{\circ}$ & $31.3^{\circ}$
\end{tabular}

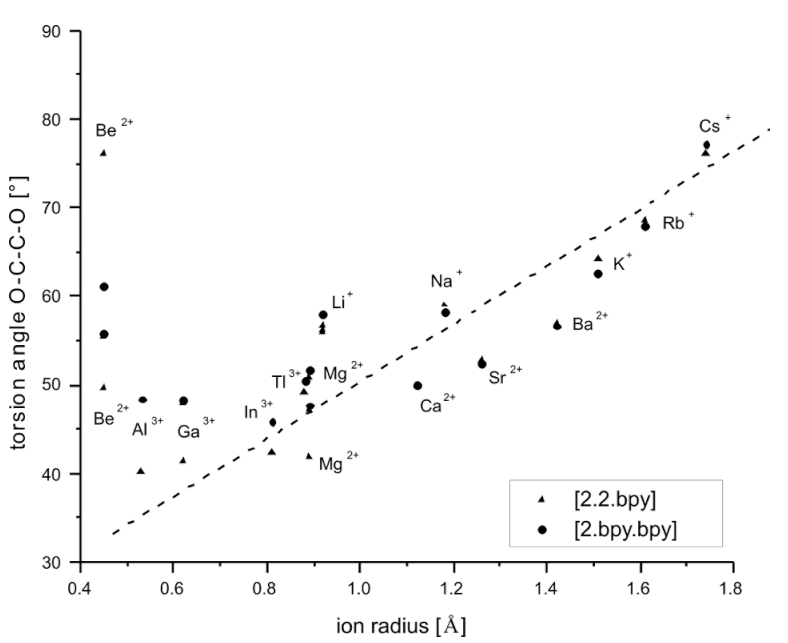

Figure 14: RB3LYP/LANL2DZp torsion angle O-C-C-O for $[\mathrm{M} \subset 2 \text { 2.2.bpy }]^{\mathrm{m}+}$ and $[\mathrm{M} \subset 2 \text {.bpy.bpy }]^{\mathrm{m}+}$ plotted against the ionic radius of $\mathrm{M}^{\mathrm{m}+}$ (dashed line represents the observed trend).

exceptions of the linear trend are the cryptates with $\mathrm{Be}^{2+}, \mathrm{Ga}^{3+}$, $\mathrm{Al}^{3+}$ and $\mathrm{Li}^{+}$. As explained above, $\mathrm{Be}^{2+}$ cation presents a special case for both cryptates. In $[\mathrm{Be} \subset 2 \text {.bpy.bpy }]^{2+}$, the coordination sphere of the cation consists of four nitrogen atoms, viz., three coming from bpy-groups and the fourth being a bridgehead nitrogen. According to this, the cryptate in the $C_{l}$ symmetry, which is more stable than the $C_{2}$ symmetry, shows two $\mathrm{N}_{\mathrm{sp} 2}-\mathrm{C}-\mathrm{C}-\mathrm{N}_{\mathrm{sp} 2}$ twist angles: one of $-0.3^{\circ}$, which lies above and one of $-42.9^{\circ}$, which fits well in the general linear trend. In the case of $[\mathrm{Be} \subset 2.2 . b p y]^{2+}$ the cation is again fourfold coordinated and shifted to one of the bridgehead nitrogen atoms, though this time one of the $\mathrm{O}$-atoms is included in the coordination sphere. Because of its small radius, it apparently does not need to twist the chelating group as much as one would expect from the extrapolation of the other values. Similar behavior can be ascribed to other small cations: $\mathrm{Al}^{3+}, \mathrm{Li}^{+}$and $\mathrm{Ga}^{3+}$, while $[\mathrm{Ga} \subset 2.2 . \mathrm{bpy}]^{3+}$ in $C_{2}$ symmetry is present as a transition state, which can additionally contribute to the observed deviation. Throughout the series, cryptates change their stereochemistry. The twist angles for the smaller cations are negative and therefore the cryptates show a $\lambda$ configuration; the larger ions cause positive angles and as a result the cryptates have a $\delta$ configuration.
Finally, the $\mathrm{O}-\mathrm{C}-\mathrm{C}-\mathrm{O}$ torsion angles show the smallest range of all twist angles calculated here, though they are somewhat larger than the $\mathrm{O}-\mathrm{C}-\mathrm{C}-\mathrm{O}$ angles found for $[\mathrm{M} \subset 2 \text { 2.2.phen }]^{\mathrm{m}+}$ and $[\mathrm{M} \subset 2 \text {.phen.phen }]^{\mathrm{m}+}[1]$. The small values indicate that the twist of the molecules in this region is less important for the mutual adjustment of the host and guest. Apart from the exceptions described above, the coordination of the $\mathrm{O}$ atoms is mostly important for the larger cations for which Figure 14 shows a good linear trend, while the smaller ions deviate from it. In both cryptate series the angles are positive and become larger in the studied main groups. Hence, they show $\delta$ stereochemistry.

The four presented torsion angles describe the twist of the cryptand around the cations. The $\mathrm{CH}_{2}-\mathrm{N}_{\mathrm{sp} 3}-\mathrm{N}_{\mathrm{sp} 3}-\mathrm{CH}_{2}$ and $\left(\mathrm{CH}_{2}\right)_{2}-\mathrm{N}_{\mathrm{sp} 3}-\mathrm{N}_{\mathrm{sp} 3}-\left(\mathrm{CH}_{2}\right)_{2}$ angles lie in the middle of the molecule, pointing to the bipyridine and glycole building blocks, respectively. The $\mathrm{N}_{\mathrm{sp} 2}-\mathrm{C}-\mathrm{C}-\mathrm{N}_{\mathrm{sp} 2}$ and $\mathrm{O}-\mathrm{C}-\mathrm{C}-\mathrm{O}$ angles lie above and under the middle of the molecule and the hosted cation at these molecular parts.

Comparison of the data given in Table 1 and Table 2 shows a mutual shift in the calculated values of the twist angles at the respective molecule halves. While the magnitude of the $\mathrm{CH}_{2}-\mathrm{N}_{\mathrm{sp} 3}-\mathrm{N}_{\mathrm{sp} 3}-\mathrm{CH}_{2}$ or $\left(\mathrm{CH}_{2}\right)_{2}-\mathrm{N}_{\mathrm{sp} 3}-\mathrm{N}_{\mathrm{sp} 3}-\left(\mathrm{CH}_{2}\right)_{2}$ angle becomes smaller, the $\mathrm{N}_{\mathrm{sp} 2}-\mathrm{C}-\mathrm{C}-\mathrm{N}_{\mathrm{sp} 2}$ or $\mathrm{O}-\mathrm{C}-\mathrm{C}-\mathrm{O}$ angle is getting larger, for both cryptates alike, with the main exception presented by earth metals bound by [2.2.bpy], see Figure 15 and Figure 16. Hence, the cryptands coil around the hosted cations in order to get more tilted and closer to them.

As shown above, the analysis of the computed complexation energies plotted against the ionic radii allows conclusions to be made about the stability order of the studied endohedral cryptate complexes. Thereby the preferred selectivity of the alkaline earth ions plays the more important role, since the alkali cations are not very sensitive in this range, as the ion radius difference for $\mathrm{Li}^{+}, \mathrm{Na}^{+}$and $\mathrm{K}^{+}$is too large. The observed preference for the cation size can be correlated with the cavity size and, hence, with the selectivity of the cryptand. An overview of the preferred ion selectivity of several cryptand families recently studied in our group ([1-4] and the present contribution) is given in Table 10 . 

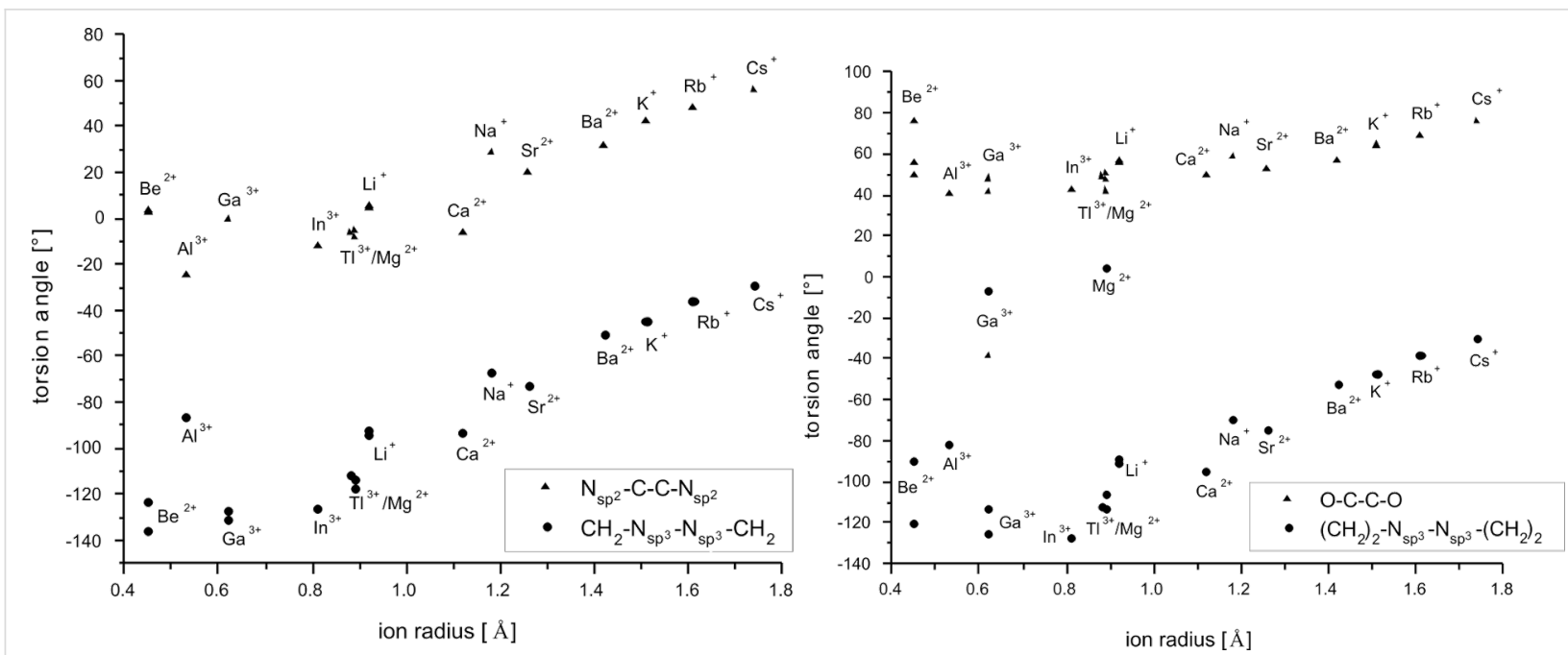

Figure 15: Reverse development of the calculated torsion angles on the respective cryptate sides for [2.2.bpy]

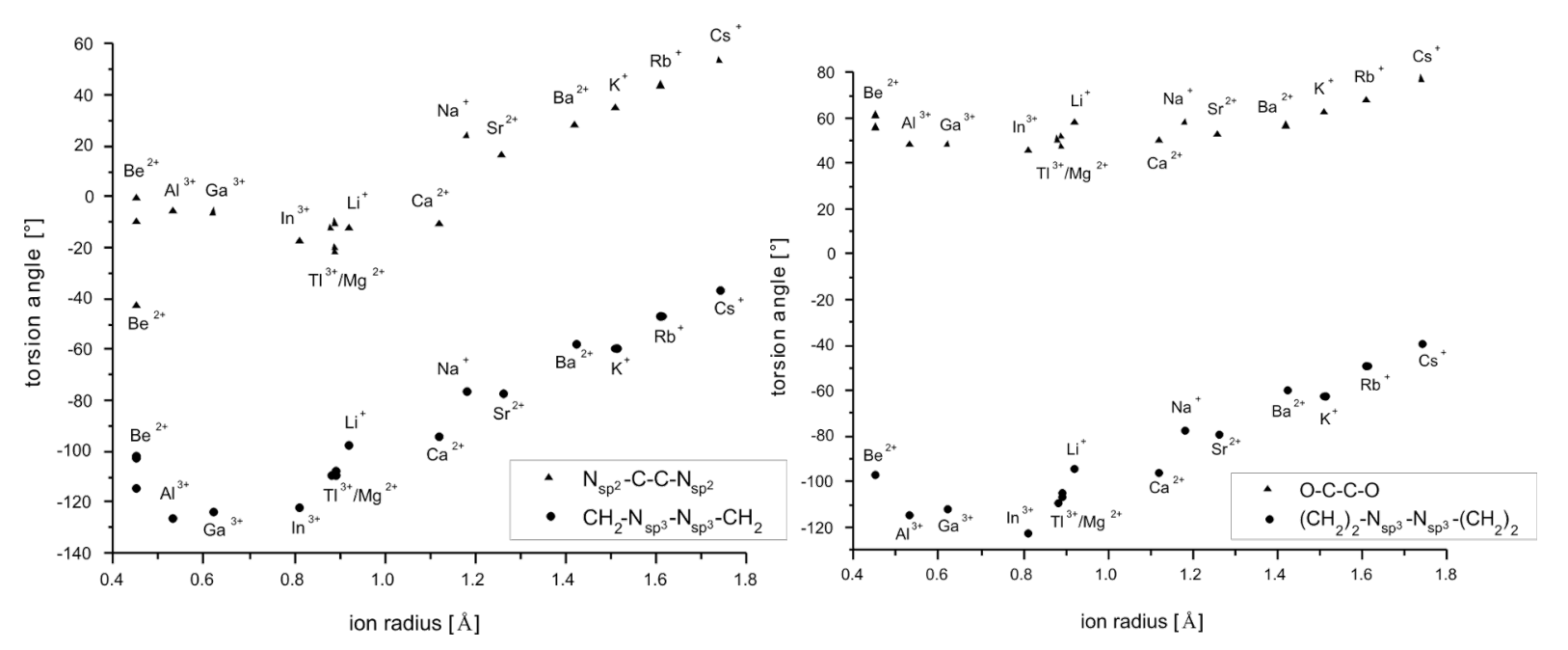

Figure 16: Reverse development of the calculated torsion angles on the respective cryptate sides for [2.bpy.bpy].

Table 10: Preferred ion selectivity of recently studied cryptands (no.: row number reflecting the cavity size and flexibility of the cryptand).

\begin{tabular}{|c|c|c|c|}
\hline no. & host & preferred alkali ion & preferred alkaline earth ion \\
\hline I & [2.2.2] & $\mathrm{K}>\mathrm{Rb}$ & $\mathrm{Ba}>\mathrm{Sr}$ \\
\hline la & [N2N2N2] & $\mathrm{K}>\mathrm{Rb}$ & $\mathrm{Ba}>\mathrm{Sr}$ \\
\hline II & [2.2.bpy] & $\mathrm{K}>\mathrm{Rb}$ & $\mathrm{Sr} \approx \mathrm{Ba}$ \\
\hline III & [2.2.phen] & $\mathrm{K}>\mathrm{Na}$ & $\mathrm{Sr}>\mathrm{Ba}$ \\
\hline IVa & [2.bpy.bpy] & $\mathrm{K}>\mathrm{Na}$ & $\mathrm{Sr}>\mathrm{Ca}$ \\
\hline $\mathrm{IVb}$ & [2.phen.phen] & $\mathrm{K}>\mathrm{Na}$ & $\mathrm{Sr}>\mathrm{Ca}$ \\
\hline V & [bpy.bpy.bpy] & $\mathrm{K}>\mathrm{Na}$ & $\mathrm{Ca} \approx \mathrm{Sr},>\mathrm{Ba}$ \\
\hline VI & [phen.phen.phen] & $\mathrm{Na}>\mathrm{K}$ & $\mathrm{Ca} \approx \mathrm{Sr},>\mathrm{Ba}$ \\
\hline VII & {$[2.2 .1]$} & $\mathrm{Na}>\mathrm{K}$ & $\mathrm{Ca}>\mathrm{Sr}$ \\
\hline VIII & {$[2.1 .1]$} & $\mathrm{Li} » \mathrm{Na}$ & $\mathrm{Mg}>\mathrm{Ca}$ \\
\hline IXa & sarcophagine & $\mathrm{Li} » \mathrm{Na}$ & $\mathrm{Be}>\mathrm{Mg}$ \\
\hline $\mathrm{IXb}$ & sepulchrate & $\mathrm{Li} » \mathrm{Na}$ & $\mathrm{Be}>\mathrm{Mg}$ \\
\hline
\end{tabular}


The cryptands are arranged according to their descending cavity size. The first in the row are [2.2.2] and [N2N2N2], which is easy to understand as they consist of conformationally nearly unhampered aliphatic molecular bars with oxygen or nitrogen donor atoms, respectively. These ligands are quite flexible, can arrange readily around the guests and, thus, can host larger cations. The list is continued by hybride cryptands, formed by a combination of [2.2.2] and [bpy.bpy.bpy] or [phen.phen.phen]. The substitution of every aliphatic di-ether chain by bipyridine or phenantroline molecular bars leads to reduced conformational flexibility and reduced cavity size. Thereby, the (phen) building block causes a stronger contraction of the cryptand hole, since the two pyridine rings are stiffened by a third, weaker aromatic six-membered ring (according to Clar's rule [72-74]) as was explained above. Hence, the subsequent substitution by (bpy) and (phen) moieties reduces the size of the cations that the cryptand is able to bind. Notably, [2.bpy.bpy] and [2.phen.phen] have nearly the same cavity size, whereas [bpy.bpy.bpy] and [phen.phen.phen] are of a similar size and close to [2.2.1].

The next are [2.2.1] and [2.1.1], which can be derived from [2.2.2] by subsequent abstraction of one or two $\mathrm{C}_{2} \mathrm{H}_{4} \mathrm{O}$ moieties, respectively. The shorter aliphatic chains connecting the bridgehead nitrogen atoms are responsible for a considerable decrease in flexibility and cavity size of the cryptands, especially in the case of [2.1.1]. Sarcophagine and sepulchrate terminate the investigated series. Both of them can be derived from [N2N2N2]. In sarcophagine, the bridgehead nitrogen atoms are replaced by carbon atoms and in sepulchrate every aliphatic chain connecting the bridgehead nitrogen atoms is shortened by two $\mathrm{CH}_{2}$ units. These structural changes lead to more constitutional rigidity of the ligands and smaller cavity sizes, such that these two prefer the smallest cations of all cryptands examined throughout our study.

To demonstrate our results more clearly, we arranged the cryptands schematically in a spiral shape shown in Figure 17, which not only includes already investigated ligands, but also provides space for further macromolecules that will be studied in future. Thereby, molecules of different size, viz., larger, smaller and those in between, will fit well into the given layout.

\section{Conclusion}

According to our DFT-calculations, [2.2.bpy] and [2.bpy.bpy] have somewhat smaller cavities than [2.2.2]. Both cryptands prefer to bind $\mathrm{Tl}^{3+}$ as earth metal and $\mathrm{K}^{+}$as alkali metal ions, although [2.2.bpy] favors $\mathrm{Rb}^{+}$as the next best and [2.bpy.bpy] favors $\mathrm{Na}^{+}$. However, it is the selectivity of the alkaline-earth metal ions that is more significant if one wants to ascertain the cavity size of a cryptand. While [2.2.bpy] can bind $\mathrm{Sr}^{2+}$ and

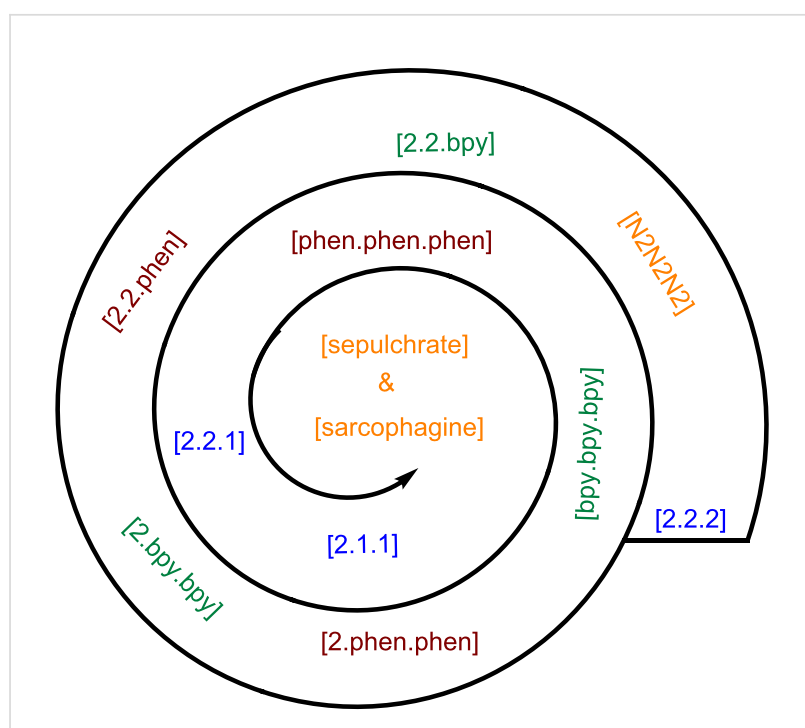

Figure 17: Trend in the preferred ion selectivity of the studied cryptands. Every cryptand family is distinguished by a different color.

$\mathrm{Ba}^{2+}$ equally well, [2.bpy.bpy] forms more stable endohedral complexes with $\mathrm{Sr}^{2+}$ followed by $\mathrm{Ca}^{2+}$. The observed difference in the ion selectivity is an indication of a decreasing cavity size from [2.2.bpy] to [2.bpy.bpy].

The flexibility of the cryptands, which is important for selective host binding, is dominated by the flexibility of the $\mathrm{CH}_{2}$ units adjacent to the bridgehead nitrogen atoms. However, the contribution of the torsion angles of the bipyridine and glycole building blocks also plays an important role, the synchronous movement of the opposite molecule sides allows the cryptand to coil around the complexed cation.

The algebraic sign of the calculated angles allows the assignment of their stereochemistry. Throughout the series of all investigated cryptates, the molecular bars adjacent to the bridgehead nitrogen atoms show $\lambda$ and the aliphatic di-ether chains $\delta$ stereochemistry, corresponding to negative and positive algebraic signs. Conversely, the steric configuration of the coordinating bipyridine moiety alternates depending on the size of the complexed metal ion.

\section{Experimental \\ Quantum chemical methods}

We performed B3LYP/LANL2DZp hybrid density functional calculations, i.e., with pseudo-potentials on the heavy elements and the valence basis set augmented with polarization functions [75-86]. During the optimization of the structures no other constraints than symmetry were applied. In addition, the resulting structures were characterized as minima, transition structures, etc., by computation of vibrational frequencies. The 
relative energies were corrected for zero-point vibrational energies (ZPE). We deliberately did not include any solvent model for the sake of comparability with earlier studies [1-4] and to exclude further approximations. The GAUSSIAN suite of programs was used [87].

\section{Acknowledgments}

The authors gratefully acknowledge financial support from the Deutsche Forschungsgemeinschaft and the Regionales Rechenzentrum Erlangen (RRZE) for a generous allotment of computer time. We would like to thank Prof. Tim Clark for friendly discussion and for hosting this work at the CCC. A referee is acknowledged for valuable suggestions.

\section{References}

1. Puchta, R.; van Eldik, R. J. Inclusion Phenom. Macrocyclic Chem. 2008, 60, 383-392. doi:10.1007/s10847-007-9388-y

2. Galle, M.; Puchta, R.; van Eikema Hommes, N. J. R.; van Eldik, R. Z. Phys. Chem. 2006, 220, 511-523. doi:10.1524/zpch.2006.220.4.511

3. Puchta, R.; Meier, R.; van Eldik, R. Aust. J. Chem. 2007, 60, 889-897. doi:10.1071/CH07238

4. Puchta, R.; van Eldik, R. Eur. J. Inorg. Chem. 2007, 1120-1127. doi:10.1002/ejic.200600715

5. Haber, F. Angew. Chem. 1927, 40, 303-314. doi:10.1002/ange.19270401103

6. Bayer, E.; Fiedler, H.; Hock, K.-L.; Otterbach, D.; Schenk, G.; Voelter, W. Angew. Chem. 1964, 76, 76-83. doi:10.1002/ange.19640760203 Angew. Chem., Int. Ed. Engl. 1964, 3, 325-332. doi:10.1002/anie.196403251 and literature cited therein.

7. Lehn, J.-M. Supramolecular Chemistry; VCH: Weinheim, Germany, 1995. doi:10.1002/3527607439

8. Vögtle, F. Supramolekulare Chemie; Teubner: Stuttgart, Germany, 1992.

9. Jaouen, G., Ed. Bioorganometallics; Wiley-VCH: Weinheim, Germany, 2006.

10. Schalley, C. A., Ed. Analytical Methods in Supramolecular Chemistry; Wiley-VCH: Weinheim, Germany, 2007.

11. Schatz, J. Collect. Czech. Chem. Commun. 2004, 69, 1169-1194. doi:10.1135/cccc20041169

12. Puchta, R.; Clark, T.; Bauer, W. J. Mol. Model. 2006, 12, 739-747. doi:10.1007/s00894-005-0079-6

13. Garska, B.; Tabatabai, M.; Ritter, H. Beilstein J. Org. Chem. 2010, 6, 784-788. doi:10.3762/bjoc.6.83

14. Sliwa, W.; Kozlowski, C. Calixarenes and Resorcinarenes; Wiley-VCH: Weinheim, Germany, 2009.

15. Gutsche, C. D. Calixarenes: An Introduction; Royal Society of Chemistry: Cambridge, 2008.

16. Fifere, A.; Marangoci, N.; Maier, S.; Coroaba, A.; Maftei, D.; Pinteala, M. Beilstein J. Org. Chem. 2012, 8, 2191-2201. doi:10.3762/bjoc.8.247 And literature cited therein.

17. Pedersen, C. J. Angew. Chem. 1988, 100, 1053-1059. doi:10.1002/ange.19881000805

Angew. Chem., Int. Ed. Engl. 1988, 27, 1021-1027. doi:10.1002/anie.198810211 And literature cited therein.
18. Cram, D. J. Angew. Chem. 1988, 100, 1041-1052. doi:10.1002/ange.19881000804 Angew. Chem., Int. Ed. Engl. 1988, 27, 1009-1020. doi:10.1002/anie.198810093 And literature cited therein.

19. Lehn, J.-M. Angew. Chem. 1988, 100, 91-116. doi:10.1002/ange.19881000110 Angew. Chem., Int. Ed. Engl. 1988, 27, 89-112. doi:10.1002/anie.198800891 And literature cited therein.

20. Ellermann, J.; Bauer, W.; Schütz, M.; Heinemann, F. W.; Moll, M. Monatsh. Chem. 1998, 129, 547-566. doi:10.1007/PL00013467

21. Hausner, S. H.; Striley, C. A. F.; Krause-Bauer, J. A.; Zimmer, H. J. Org. Chem. 2005, 70, 5804-5817. doi:10.1021/jo050281z

22. Power, N. P.; Dalgarno, S. J.; Atwood, J. L. New J. Chem. 2007, 31, 17-20. doi:10.1039/b615947h

23. Lehn, J.-M. Acc. Chem. Res. 1978, 11, 49-57. doi:10.1021/ar50122a001

24. Dietrich, B.; Viout, P.; Lehn, J.-M. Macrocyclic Chemistry; VCH: Weinheim, Germany, 1993.

25. Saalfrank, R. W.; Dresel, A.; Seitz, V.; Trummer, S.; Hampel, F.; Teichert, M.; Stalke, D.; Stadler, C.; Daub, J.; Schünemann, V.; Trautwein, A. X. Chem.-Eur. J. 1997, 3, 2058-2062. doi:10.1002/chem.19970031222

26. Saalfrank, R. W.; Löw, N.; Kareth, S.; Seitz, V.; Hampel, F.; Stalke, D.; Teichert, M. Angew. Chem. 1998, 110, 182-184. doi:10.1002/(SICI)1521-3757(19980116)110:1/2<182::AID-ANGE182> 3.0.CO;2-S Angew. Chem., Int. Ed. 1998, 37, 172-175. doi:10.1002/(SICI)1521-3773(19980202)37:1/2<172::AID-ANIE172>3.0 .CO;2-0

27. Puchta, R.; Seitz, V.; van Eikema Hommes, N. J. R.; Saalfrank, R. W. J. Mol. Model. 2000, 6, 126-132. doi:10.1007/s0089400060126

28. Saalfrank, R. W.; Deutscher, C.; Maid, H.; Ako, A. M.; Sperner, S.; Nakajima, T.; Bauer, W.; Hampel, F.; Heß, B. A.; van Eikema Hommes, N. J. R.; Puchta, R.; Heinemann, F. W. Chem.-Eur. J. 2004, 10, 1899-1905. doi:10.1002/chem.200306050

29. Saalfrank, R. W.; Nakajima, T.; Mooren, N.; Scheurer, A.; Maid, H.; Hampel, F.; Trieflinger, C.; Daub, J. Eur. J. Inorg. Chem. 2005, 1149-1153. doi:10.1002/ejic.200400773

30. Saalfrank, R. W.; Scheurer, A.; Puchta, R.; Hampel, F.; Maid, H.; Heinemann, F. W. Angew. Chem., Int. Ed. 2007, 46, 265-268. doi:10.1002/anie.200603203 Angew. Chem. 2007, 119, 269-272. doi:10.1002/ange.200603203

31. Saalfrank, R. W.; Mooren, N.; Scheurer, A.; Maid, H.; Heinemann, F. W.; Hampel, F.; Bauer, W. Eur. J. Inorg. Chem. 2007, 4815-4822. doi:10.1002/ejic.200700579

32. Woisetschläger, O. E.; Scheurer, A.; Saalfrank, R. W.; Beck, W. Z. Anorg. Allg. Chem. 2007, 633, 2141-2143. doi:10.1002/zaac.200700350

33. Puchta, R.; Roling, B.; Scheurer, A.; Weiskopf, V.; Hampel, F.; van Eikema Hommes, N. J. R.; Hummel, H.-U. Solid State Ionics 2008 , 179, 489-494. doi:10.1016/j.ssi.2008.02.060

34. Saalfrank, R. W.; Reimann, U.; Scheurer, A.; Hampel, F.; Goebel, C. Herbst-Irmer, R. Z. Naturforsch. 2009, 64b, 365-370.

35. Saalfrank, R. W.; Scheurer, A.; Puchta, R.; Hampel, F.; Maid, H.; Heinemann, F. W. Angew. Chem. 2007, 119, 269-272. doi:10.1002/ange.200603203 Angew. Chem., Int. Ed. 2007, 46, 265-268. doi:10.1002/anie.200603203

36. Saalfrank, R. W.; Scheurer, A. Top. Curr. Chem. 2012, 319, 125-170. 
37. Dietrich, B.; Lehn, J.-M.; Sauvage, J. P. Tetrahedron Lett. 1969, 10, 2885-2888. doi:10.1016/S0040-4039(01)88299-X

38. Demlov, E.; Demlov, Z. Phase-transfer catalysis; Mir Press: Moscow, 1987.

39. Bhatnagar, M.; Awasthy, A.; Sharma, U. Main Group Met. Chem. 2004, 27, 163-168. doi:10.1515/MGMC.2004.27.3.163

40. Reed, C. D.; Launay, G. G.; Carroll, M. A. J. Fluorine Chem. 2012, 143, 231-237. doi:10.1016/j.jluchem.2012.07.015

41. Li, J.-H.; Shih, J.-S. J. Chin. Chem. Soc. 1999, 46, 885-892.

42. Housecroft, C. E. Clusterverbindungen von Hauptgruppenelementen; VCH: Weinheim, Germany, 1995.

43. Müller, W. H. Naturwissenschaften 1970, 57, 248. doi:10.1007/BF01010278

44. Müller, W. H.; Müller, W. A. Naturwissenschaften 1974, 61, 455. doi:10.1007/BF00597212

45. Lehn, J.-M.; Montavon, F. Helv. Chim. Acta 1978, 61, 67-82. doi:10.1002/hlca.19780610107

46. Kirch, M.; Lehn, J.-M. Angew. Chem. 1975, 87, 542-543. doi:10.1002/ange.19750871507 Angew. Chem., Int. Ed. Engl. 1975, 14, 555-556. doi:10.1002/anie.197505551

47. Ajgaonkar, H. S.; Khopkar, S. M. Chem. Anal. 1999, 44, 61-66.

48. Tait, D.; Haase, G.; Wiechen, A. Kiel. Milchwirtsch. Forschungsber. 1998, 50, 207-211.

49. Burai, L.; Scopelliti, R.; Tóth, E. Chem. Commun. 2002, 2366-2367. doi:10.1039/b206709a

50. Rodriguez-Urbi, J.-C.; Alpha, B.; Plancherel, D.; Lehn, J.-M. Helv. Chim. Acta 1984, 67, 2264-2269. doi:10.1002/hlca.19840670833

51. Dürr, H.; Zengerle, K.; Trierweiler, H. P. Z. Naturforsch., B 1988, 43, 361-367.

52. Alpha, B.; Lehn, J.-M.; Mathis, G. Angew. Chem. 1987, 99, 259-261. doi:10.1002/ange.19870990323

Angew. Chem., Int. Ed. Engl. 1987, 26, 266-267. doi:10.1002/anie.198702661

53. Alpha, B.; Balzani, V.; Lehn, J.-M.; Perathoner, S.; Sabbatini, N. Angew. Chem. 1987, 99, 1310-1311. doi:10.1002/ange.19870991226 Angew. Chem., Int. Ed. Engl. 1987, 26, 1266-1267. doi:10.1002/anie.198712661

54. Mathis, G.; Lehn, J.-M. Macropolycyclic rare earth complexes and their use as fluorescent markers. French Patent FR2570703, March 28, 1986.

55. Bazin, H.; Mathis, G. Novel nucleoside or nucleotide fluorescent conjugates, preparation method and uses. WO Patent WO1999018114, April 15, 1999.

56. Billadeau, M. A.; Gudibande, S. R.; Leland, J. K.; Shen, L. Simultaneous assay method using lanthanide chelates as the luminophore for multiple labels. WO Patent WO1996041177, Dec 19, 1996.

57. Buet, P.; Gersch, B.; Grell, E. J. Fluoresc. 2001, 11, 79-87. doi:10.1023/A:1016611500005

58. Coldwall, J. B.; Felton, C. E.; Harding, L. P.; Moon, R.; Pope, S. J. A.; Rice, C. R. Chem. Commun. 2006, 5048-5050. doi:10.1039/b612662f

59. Alpha, B.; Anklam, E.; Deschenaux, R.; Lehn, J.-M.; Pietraskiewicz, M. Helv. Chim. Acta 1988, 71, 1042-1052. doi:10.1002/hlca.19880710515

60. Charbonnière, L. J.; Hildebrandt, N.; Ziessel, R. F.; Löhmannsröben, H.-G. J. Am. Chem. Soc. 2006, 128, 12800-12809. doi:10.1021/ja062693a

61. Alzakhem, N.; Bischof, C.; Seitz, M. Inorg. Chem. 2012, 51, 9343-9349. doi:10.1021/ic3010568

62. Footnote of Table 6: $a:$ NImag $=6, b:$ NImag $=5$.
63. Gutmann, V. The Donor-Acceptor Approach to Molecular Interaction; Plenum: New York, 1978.

64. Gutmann, V. Electrochim. Acta 1976, 21, 661-670. doi:10.1016/0013-4686(76)85034-7

65. Schmeisser, M.; Illner, P.; Puchta, R.; Zahl, A.; van Eldik, R. Chem.-Eur. J. 2012, 18, 10969-10982. doi:10.1002/chem.201200584

66. Puchta, R.; Galle, M.; van Eikema Hommes, N.; Pasgreta, E.; van Eldik, R. Inorg. Chem. 2004, 43, 8227-8229. doi:10.1021/ic0487979 And references cited therein.

67. Puchta, R.; van Eikema Hommes, N.; van Eldik, R. Helv. Chim. Acta 2005, 88, 911-922. doi:10.1002/hlca.200590085 And references cited therein.

68. Farver, O. Acta Chem. Scand. 1972, 26, 534-540. doi:10.3891/acta.chem.scand.26-0534

69. Kul'ba, F. Y.; Makashev, Y. A.; Guller, B. D.; Kiselev, G. V. Russ. J. Inorg. Chem. 1962, 7, 351-353.

70. Ravikumar, I.; Lakshminarayanan, P. S.; Suresh, E.; Ghosh, P. Beilstein J. Org. Chem. 2009, 5, No. 41. doi:10.3762/bjoc.5.41

71. Caron, A.; Guilhelm, J.; Riche, C.; Pascard, C.; Alpha, B.; Lehn, J.-M.; Rodriguez-Ubis, J. C. Helv. Chim. Acta 1985, 68, 1577-1582. doi:10.1002/hlca.19850680609

72. Clar, E. Polycyclic Hydrocarbons; Academic Press: London, 1964. 73. Clar, E. The Aromatic Sextet; John Wiley \& Sons: New York, 1972.

74. Randić, M. Chem. Rev. 2003, 103, 3449-3606. doi:10.1021/cr9903656

75. Becke, A. D. J. Chem. Phys. 1993, 98, 5648-5652. doi:10.1063/1.464913

76. Lee, C.; Yang, W.; Parr, R. G. Phys. Rev. B 1988, 37, 785-789. doi:10.1103/PhysRevB.37.785

77. Stephens, P. J.; Devlin, F. J.; Chabalowski, C. F.; Frisch, M. J. J. Phys. Chem. 1994, 98, 11623-11627. doi:10.1021/j100096a001

78. Dunning, T. H., Jr.; Hay, P. J. Mod. Theor. Chem. 1976, 3, 1-28.

79. Hay, P. J.; Wadt, W. R. J. Chem. Phys. 1985, 82, 270-283. doi:10.1063/1.448799

80. Wadt, W. R.; Hay, P. J. J. Chem. Phys. 1985, 82, 284-298. doi:10.1063/1.448800

81. Hay, P. J.; Wadt, W. R. J. Chem. Phys. 1985, 82, 299-310. doi:10.1063/1.448975

82. Huzinaga, S., Ed. Gaussian Basis Sets for Molecular Calculations; Elsevier: Amsterdam, 1984.

83. Puchta, R.; Meier, R.; van Eikema Hommes, N. J. R.; van Eldik, R. Eur. J. Inorg. Chem. 2006, 4063-4067. doi:10.1002/ejic.200600483 See for example that the performance of the computational level employed in this study is well documented.

84. Scheurer, A.; Maid, H.; Hampel, F.; Saalfrank, R. W.; Toupet, L.; Mosset, P.; Puchta, R.; van Eikema Hommes, N. J. R. Eur. J. Org. Chem. 2005, 2566-2574. doi:10.1002/ejoc.200500042 See for example that the performance of the computational level employed in this study is well documented.

85. Illner, P.; Zahl, A.; Puchta, R.; van Eikema Hommes, N.; Wasserscheid, P.; van Eldik, R. J. Organomet. Chem. 2005, 690, 3567-3576. doi:10.1016/j.jorganchem.2005.03.029 See for example that the performance of the computational level employed in this study is well documented.

86. Weber, C. F.; Puchta, R.; van Eikema Hommes, N. J. R.; Wasserscheid, P.; van Eldik, R. Angew. Chem. 2005, 117, 6187-6192. doi:10.1002/ange.200501329

Angew. Chem., Int. Ed. 2005, 44, 6033-6038. doi:10.1002/anie.200501329 See for example that the performance of the computational level employed in this study is well documented. 
87. Gaussian 09, Revision A.02; Gaussian, Inc.: Wallingford, CT, 2009.

\section{License and Terms}

This is an Open Access article under the terms of the Creative Commons Attribution License

(http://creativecommons.org/licenses/by/2.0), which permits unrestricted use, distribution, and reproduction in any medium, provided the original work is properly cited.

The license is subject to the Beilstein Journal of Organic Chemistry terms and conditions:

(http://www.beilstein-journals.org/bjoc)

The definitive version of this article is the electronic one which can be found at:

doi:10.3762/bjoc. 9.142 